Portland State University

PDXScholar

\title{
The Degree of Acculturation and Success Patterns in Three Generations of the Japanese Americans in the Portland Area
}

Toshimasa Fujii

Portland State University

Follow this and additional works at: https://pdxscholar.library.pdx.edu/open_access_etds

Part of the Family, Life Course, and Society Commons, Japanese Studies Commons, and the Sociology of Culture Commons

Let us know how access to this document benefits you.

\section{Recommended Citation}

Fujii, Toshimasa, "The Degree of Acculturation and Success Patterns in Three Generations of the Japanese Americans in the Portland Area" (1980). Dissertations and Theses. Paper 3098.

https://doi.org/10.15760/etd.3094

This Thesis is brought to you for free and open access. It has been accepted for inclusion in Dissertations and Theses by an authorized administrator of PDXScholar. Please contact us if we can make this document more accessible: pdxscholar@pdx.edu. 
AN ABSTRACT OF THE THESIS OF TOshimasa Fujii for the Master of Arts in Sociology presented July 25, 1980.

Title: The Degree of Acculturation and Success Patterns in Three Generations of the Japanese Americans in the Portland Area.

APPROVED BY MEMBERS QF RHE THESIS COMMITTEE:

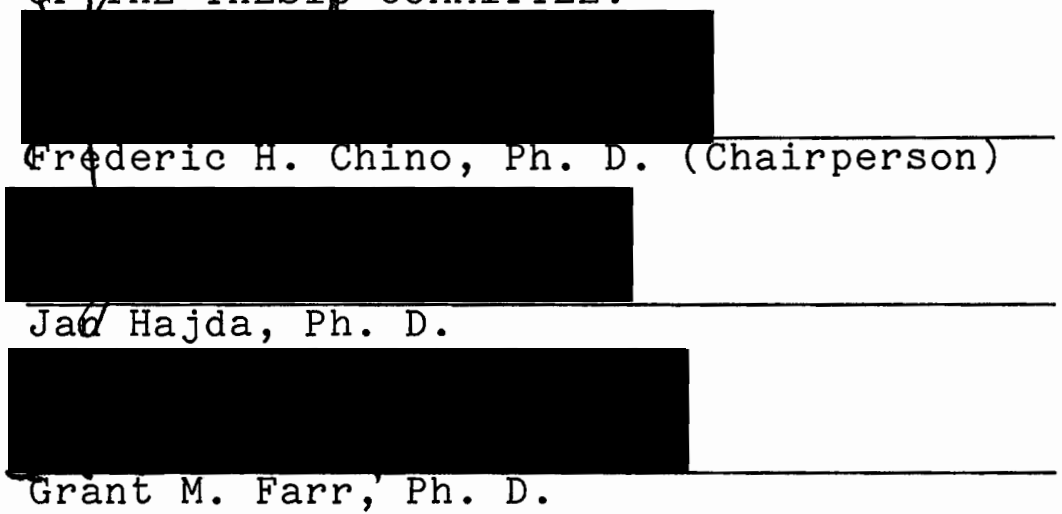

Past research shows that Japanese Americans have been successful occupationally, financially and educationally. This thesis examines factors leading to this success. It is generally argued that the greater the congruence between minority and majority value systems, the less likely conflict would be generated in the minority group's acculturation. There appear to be two opposed aspects in the acculturation of the Japanese Americans, relinquishment or retention of traditional Japanese values. Also important is the degree to which Japanese Americans identify themselves as American, or Japanese, or some mixture. This thesis focusses on the following questions: What types of values have been relinquished or retained? If some are retained and others 
relinquished, are those that are retained congruent with the American value system and those relinquished incongruent? What intergenerational and intragenerational differences are observable in the pattern of retention/relinquishment of traditional Japanese values? To what extent does ethnic identity affect success?

From these questions it was hypothesized: 1) those who have retained the traditional Japanese values which are congruent with the dominant American value system are more likely to be successful than those who have not; 2) those who have relinquished the traditional Japanese values which are incongruent with the dominant American value system are more likely to be successful than those who have not; 3 ) those who possess a strong American identity are more likely to be successful than those who have a more Japanese identity. The findings reflected different patterns in the value system of each generation. Traditional values were strongly retained among the Issei, Protestant ethic values were pervasive among the Nisei, and the Sansei value system was different from both. The so-called "now" or current values of appreciation of human feelings, good personal relations, and freedom were strongly embraced by the Sansei.

Intragenerational analysis revealed that an individual, regardless of generation, would be successful if he/she rejected those Japanese values incompatible with the Protestant ethic, supporting the second hypothesis. The first 
hypothesis, however, was rejected in some cases. Among the Issei, a negative relationship existed between the embracement of Protestant ethic values and financial success. Also, among the Issei and Sansei, embracement of Protestant ethic values was negatively correlated with educational achievement. Otherwise, embracement of Protestant ethic values can be a predictor of success. The findings also showed that educational achievement is closely related to a value orientation. Acculturation significantly influences, and is influenced by, level of educational achievement.

In the relationship between self-judged ethnic identity and success, among the Issei, a strong positive correlation between American identity and occupational as well as educational success obtained. Among the Sansei, a positive correlation between Japanese identity and financial success was found. One explanation is that part of their "now" values are congruent with traditional Japanese values which stress harmonious stability. Despite some exceptions, one can conclude from these findings that success patterns of the Japanese Americans are closely related to whether the dominant American value system, which stresses individualism, is embraced or rejected, although intergenerational differences do exist. 
THE DEGREE OF ACCULTURATION AND SUCCESS PATTERNS

IN THREE GENERATIONS OF THE JAPANESE AMERICANS

IN THE PORTLAND AREA

by

TOSHIMASA FUJII

A thesis submitted in partial fulfillment of the requirements for the degree of

MASTER OF ARTS

in

SOCIOLOGY

Portland State University

1980 
TO THE OFFICE OF GRADUATE STUDIES AND RESERACH:

The members of the Committee approve the thesis of Toshimasa Fujii presented July 25, 1980
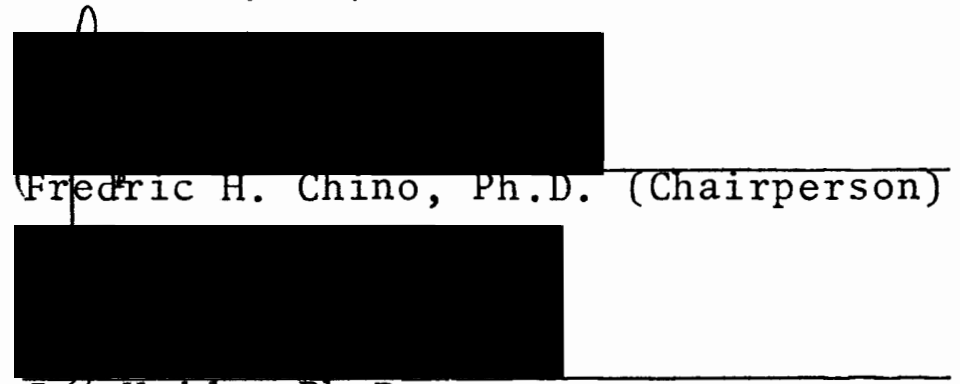

Jäh Hajda, Ph.D.

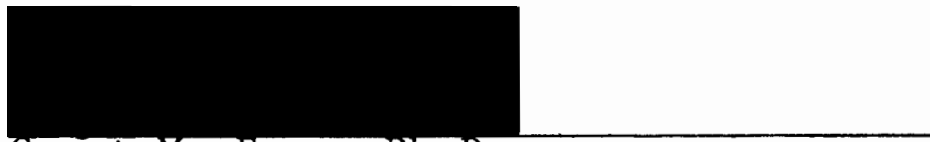

Grant M. Farr, Ph.D.

APPROVED :

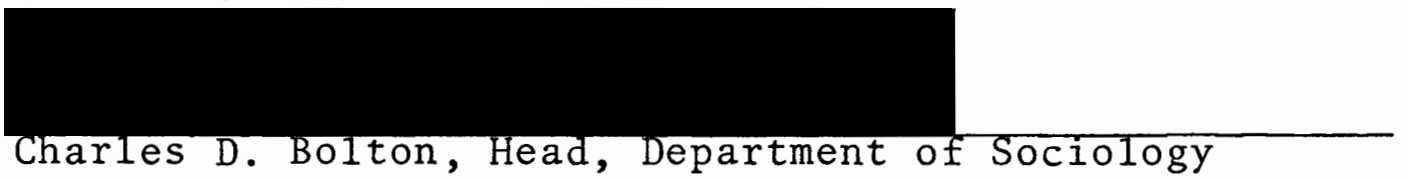

Stanley E. Fauch, Dean of Graduate Studies and Reserach 
This study is dedicated to my parents:

\author{
Mr. Takashi Fujii \\ and
}

Mrs. Itsuko Fujii 


\section{ACKNOWLEDGMENTS}

Because in this study the writer is indebted to a number of people, it is fairly difficult to acknowledge his debts. However, there are several to whom the writer owes special debts.

The writer's most important recognition is first to Mr. and Mrs. Takashi Fujii, his parents in Sapporo, Japan. Without their material assistance, this study would have been impossible. Dr. Frederic H. Chino, the chairperson of the thesis committee, advised the writer in many respects. It should also be mentioned that his personal experience as a Nisei (second-generation) Japanese American has provided valuable insights on the subject of this thesis. Dr. Jan Hajda, a member of the thesis committee, had a great influence on the writer throughout his graduate study at Portland State University, especially in a series of theory courses. Besides his academic encouragement, he has been a great intellectual stimulus to the writer throughout the period of his study in the United States. Therefore, the writer would like to express his special thanks to him. Dr. Grant M. Farr, also a member of the thesis committee, helped the writer in regard to methodology.

The writer would also like to record here his warmest 
acknowledgments to Mrs. Mary K. L. Kern and Mrs. Marjorie S. Terdal for their kind instruction in the courses in English composition. The writer learned a great deal from them regarding composition in English throughout the summer and the fall terms of 1977. It is not an exaggeration to state that this thesis would not have existed without the knowledge bestowed by them. The writer must emphasize, however, that he is solely responsible for any defects to be found in this study.

The writer is grateful to Rebecca A. Dinsmore, his fiancee, for her encouragement while he was engaged in this study.

Finally, the writer wishes to express his gratitude to the Kondo's -- Mr. and Mrs. Sam H. Kondo (Issei) and their sons (Nisei) and their grandchildren (Sansei) - - who have shown the writer an excellent example of the life styles of the three-generation of Japanese Americans. The motivation for this study was the result of the writer's personal interactions with them.

Toshimasa Fujii

Portland, Oregon

July 1980 
TABLE OF CONTENTS

PAGE

ACKNOWLEDGMENTS . . . . . . . . . . . . . . . . . iv

LIST OF TABLES . . . . . . . . . . . . . . . . ix

LIST OF FIGURES . . . . . . . . . . • . •

DIAGRAM . . . . . . . . . . . . . . . $x$

CHAPTER

I STATEMENT OF THE PROBLEM • . . . . . . 1

Japanese Americans and

Their Success . . . . . . . . 1

Plausible Factors of

Their Success . . . . . . . . 4 4

Transformational Aspects

of the Culture......... . 5

Objects of the Study . . . . . . 7

Reference for Chapter I . . . . 12

I T THE HISTORICAL BACKGROUND . . . . . . 14

How Did It Start? . . . . . . 14

Nature of the Immigrants . . . . 17

Japanese in Japan and

Japanese in America . . . . . 20

Racism in American Society . . . 22

The Current Trend in the

Community of the Japanese

Ame ricans . . . . . . . . . 
Reference for Chapter II . . .

II I CONCEPTUALIZATION OF THE STUDY • •

The Notion of Values . . . . .

Japanese Immigrants and the

Notion of Reference Groups... .

Personality Structure of

Japanese Immigrants . . . . • •

Foundations of the Traditional

Japanese Value System . . . . .

The Value Systems of the

Japanese Americans . . . . . .

"Assinilation" and

"Acculturation" . . . . . . .

Compatibility and Incompatibility of the Japanese Values with the

American Value System . . . .

Some Notes Regarding Success

Orientation of Japanese

Americans . . . . . . . . .

Study Hypotheses . . . . . . .

Reference for Chapter III . . .

IV PROCEDURE OF THE STUDY..$\cdot$. . .

The Sampling Method . . . . .

The Issei Sample . . . . . . .

The Nisei Sample... . . . . . 63

The Sansei Sample . . . . . . 63

An Overview of the Sample . . . . 64

Data Collection . . . . . . . 65 
Measures Utilized in

the Study . . . . . . . . .

1) Degree of Acculturation . . . . . 68

2) Degree of Occupational Success . .

70

3) Degree of Financial

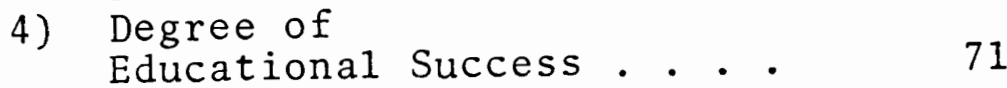

Data Processing . . . . . . . 72

Reference for Chapter IV . . . . 73

V FINDINGS . . . . . . . . . . . 74

Introduction . . . . . . . . 74

Marginal

Distribution . . . . . . . . .

Verification of the First Hypothesis . . . . . . .

Verification of the Second Hypothesis . . . . . . . .

Reference for Chapter V . . . .

VI CONCLUSION

B IBL IOGRAPHY • • • . • • • • • . 


\section{LIST OF TABLES}

TABLE

PAGE

1 Japanese Population in the Mainland United States.......... 16

I The Japanese American Population

Utilized in the Study........ 65

II The Response Characteristics . . . . . 66

IV Respondent Ratio by Generation and Gender ... . . . . . . 67

V Marginal Distribution by Generation . . 75

VI The Degree of Embracement of

Protestant Ethic Values by Occupation, Income, and Education by Generation .

VII The Degree of Embracement of Japanese Values by Occupation, Income, and Education by Generation . . . .

VIII Self-judged Ethnic Identity by Occupation, Income, and Education by Generation . . . . . . . . .

IX Statistical Associations Between Financial Achievement and Selected Other Variables in the Sansei Sample . . . 


\section{LIST OF FIGURES}

FIGURE

PAGE

1 Four Dimensions of the Acculturation-

Success Theory . . . . . . . . . .

2 Four Dimensions of the Value System

of Japanese Americans . . . . . .

DIAGRAM

DIAGRAM

PAGE

1 Causal Relation Among the Set of Variables: An Hypothesis . . . . . 99 


\section{CHAPTER I}

\section{STATEMENT OF THE PROBLEM}

Japanese Americans and Their Success ${ }^{1}$

According to the 1970 United States Census, the

Japanese Americans are the largest Asian group in the United States, with 588,000 individuals, followed by the Chinese with 435,000 , the Filipino with 340,000 , and the Korean with $70,000 .^{2}$ Approximately $72 \%$ of the Japanese Americans live in two states; Hawaii $(217,000)$ and California $(213,000)$. Other relatively populous states include New York $(20,000)$, Washington $(20,000)$ and Illinois $(18,000)$.

In $1970,33 \%$ of all working Japanese-American males were employed as professionals and managers, a higher rate than the $25 \%$ found in the U. S. as a whole. 3 In Los Angeles County, which has the largest Japanese-American population

${ }^{1}$ The term Japanese Americans is used consistently in this thesis as Americans of Japanese ancestry; that is to say, the first-generation immigrants born in Japan and their American-born children, grandchildren, and so forth.

2 Because there have been a large number of Filipino, Korean and Vietnamese immigrants in the 1970's, the ranking may be different by 1980 .

3 of the total population of the Japanese Americans, $46 \%$ were males and $54 \%$ were females. 
on the mainland of the United States, school authorities reported that children of Japanese descent had outstripped al1 others in the level of I. Q. scores (Schwartz, 1971). In issues of social pathology, it has been reported that crime rates among the Japanese Americans are consistently lower than the general crime rate for the nation. 4

The United States Census also reports data on education, and it is often noted that Japanese Americans are better educated than other ethnic groups in America. According to the statistics, the average length of their schooling was 12.5 years. Of all Japanese-American males 16 years of age and older, $70 \%$ had finished high school, compared to $54 \%$ for the United States at large. Nineteen percent of Japanese-American males had completed college education, compared to $13 \%$ of the United States as a whole. For females, $11 \%$ had completed college education which was higher than the $8 \%$ of the U. S. total for females. Regarding income, a median family income of the Japanese Americans in 1970 was $\$ 3,000$ higher than the nation's average income. 5

Because of these facts, it has often been asserted

${ }^{4}$ See, for example, Harry H. L. Kitano, Japanese Americans: The Evolution of a Subculture (1976), Chapter 9; or William Petersen, Japanese Americans: Oppression and Success (1971), Chapter 6.

${ }^{5} \mathrm{Cf}$. "Japanese, Chinese and Filipinos in the United States," and "Occupational Characteristics" in 1970 Census of Population (1973). 
that the Japanese Americans are one of the successful minorities in the United States. 6 Despite their experience as victims of racial discrimination throughout the United States, particularly their confinement in internment camps during World War II, the Japanese Americans have established a reputation as being a "middleman minority" within the hierarchy of American society. ${ }^{7}$ Their success, which was attained rapidly after World War II, has been so great that they are sometimes called America's "model minority." 8

From this characterization of the Japanese Americans, it is reasonable to raise the question: What were the crucial

${ }^{6}$ Frequent reference is made in the literature to the "success story" of the Japanese Americans. See for example, William Petersen, "Success Story, Japanese American Style," The New York Times Magazine (January 9, 1966): 20-43; and "Success Story: Outwhiting the Whites," Newsweek (June 21, 1971): $24-5$.

7 The notion of "middleman minority" has been developed in the following articles. Edna Bonacich, "A Theory of Middleman Minorities" (1973); and Harry H. L. Kitano, "Japanese Americans: The Development of a Middleman Minority" (1976). The argument is based upon the observation that Japanese Americans have achieved considerable social mobility, while other minority groups have remained in the lower strata of American society. This is noticeable especially when their occupations are considered. Their competitive advantage is salient in such fields as business and agriculture. See Percentage Distribution of Japanese and A11 Employed People by Occupational Groups, 1940-1970, Table 4, in Joseph Hraba, American Ethnicity (1979), p. 332 .

${ }^{8}$ The title of "model minority" has been bestowed primarily upon the second-generation Japanese Americans because of their educational and occupational success with a relatively low rate of social problems. It has been pointed out, however, that this judgment is made exclusively from the point of view of dominant white majority. 
factors which made it possible for them to succeed in American society?

Plausible Factors in Their Success

What were the crucial factors which made it possible for Japanese Americans to succeed in American society? One plausible explanation focuses on the Japanese American's emphasis on the value of formal education. 9 It is widely believed that education is the key to success in the United States. The median years of schooling completed by the Japanese Americans are greater than the nation's average. Another explanation attributes the success of the Japanese Americans to their emphasis upon such industrial practices and values as hard work, thrift and self-control. ${ }^{10}$ Those values are quite congruent with the dominant value orientations of the American middle class.11 Consequently, it is often argued that the Japanese Americans have been able to absorb the dominant cultural pattern in the United States without having difficulties experienced by other immigrant groups.

${ }^{9}$ For example, see Audrey J. Schwartz, op. cit., or Harry H. L. Kitano, "Japanese Americans: The Development of Middleman Minority" (1976).

${ }^{10}$ For example, see William Caudil1, "Japanese-American Personality and Acculturation" (1952).

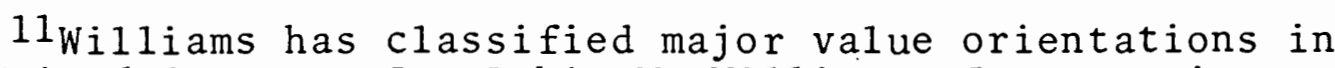
the United States. See Robin M. Williams, Jr., American Sgciety: A Sociological Interpretation (1951), pp. 388-440. Akso Cohen has conducted a study regarding the pattern of American middle class standards. See Albert K. Cohen, Delinquent Boys: The Culture of the Gang (1955), pp.87-93. 
While it is true that some values of Japanese Americans are congruent with the dominant value orientations of American society, there are other Japanese values that are incongruent with the dominant American value system. Another important factor to be considered is racism in American society. Williams (1970 [195]) has asserted that racism and related group-superiority themes are two of the major value orientations in American society.

Petersen (1971: 4) argues that color prejudice is so great among Caucasians that anyone who carries a visible stigma has little or no possibility of rising in the status structure in American society. Except for those who have visible stigma, he contends, acculturation in terms of absorption of the dominant culture seems to be one of the crucial factors for climbing up the ladder of success in the United States. This prompts a second question. If the success of the Japanese Americans is due to their successful acculturation (that is, practicing the values that are quite similar to the values of the American middle class), to what extent do three adult generations of Japanese Americans differ with respect to the degree of acculturation?

Transformational Aspects of the Culture

A seventy-nine-year old Issei $^{12}$ told the writer that when he and his wife visited his home town in Japan two years

12 Issei means first-generation immigrants born in Japan. When the generations of the Japanese Americans are 
ago for the first time in fourteen years, he realized that the traditional Japanese cultural values, beliefs and practices were so out of vogue in contemporary Japan that those characteristics seemed to have been retained more strongly among the Issei of the Japanese-American community.13 This point of view is generally agreed upon by those who are conversant with the culture of America and Japan.

However, transformation of the "traditional" values has also occurred within the Japanese-American community. Changes are easily discerned, especially between generations, the so-called generation gap. The differences between the generations are symbolized by the well-suited metaphorical expression: the Issei as the bamboo people, the Nisei as the banana people, and the Sansei as the boiled-egg people. The Issei are described as bamboo because of their shared characteristic of patience. The Issei's experience was like bamboo in the snowy country -as snow accumulates, the bamboo bends without hurting until

mentioned in general, there are certain age spans; i.e., the generations are usually distinguished by some cultural features which will be discussed in this thesis. Today, the average age of the Issei is over seventy. That of the Nisei (second generation) is between 50 and 60 , and the Sansei (third generation) is between 25 and 35. It should also be mentioned here that most "pioneer" Issei are now deceased and the Issei of this study are called Yobiyose, the family of the "pioneer" Issei. Yobiyose means the persons who were called out from Japan by their parents in America. In most cases, Yobiyose were the children of the "pioneer" Issei.

13 Based upon the writer's private interview with $\mathrm{Mr}$. Sam H. Kondo in the summer of 1978 in Portland, Oregon. 
the snow melts. The snow, in this context, means the hardships or oppression that the Issei experienced as immigrants in the United States. The Nisei are described as bananas. Although the color of the skin (outside) of the Nisei is yellow, their way of thinking (inside) is quite similar to the whites'. As for the Sansei, they are described as eggs because they are almost identical with the white Americans with respect to the way of thinking; however, there is a yellow part inside of them no matter how white they assert themselves to be. 14

The Sansei are now in their 20's or 30's. They appear to put more emphasis than the Nisei and Issei on such phases of assimilation as interracial marriage, residence in non-Japanese neighborhoods, and identification with non-Japanese social organizations and friends. At the same time, the degree of acculturation of the Sansei, in terms of transformation or modification of the traditional Japanese culture, would be predicted to be higher than that of the $N$ isei and Issei.

Objects of the Study

Many studies have been conducted with regard to the issue of "majority and minority." The term minority has

${ }^{14}$ The Sansei are sometimes described as the "bee" people because they are, like the bees, active and selfassertive compared with their Nisei parents and Issei grandparents. The writer was told this metaphorical description regarding the three generations of the Japanese Americans by several persons during his inverviews. 
been defined by wirth (1945: 347) as:
[A] group of people who, because of their physical or cultural characteristics, are singled out from the others in the society in which they live for differential and unequal treatment, and who there- fore regard themselves as objects of collective discrimination.

He continues:

The existence of a minority in a society implies the existence of a corresponding dominant group with higher social status and greater privileges. Minority status carries with it the exclusion from full participation in the life of the society. ...

Thus, the major premise for the discussion of minority is its relation to the majority; i. e., a dominant group. However, one might expect that conflict between those two groups will be reduced if the goals (or values) of a certain minority group are similar to the goals (or values) of the dominant group. Consequently, it might be hypothesized that the greater the congruence in the value systems between a minority and the majority, the less likely conflict would be generated in the process of acculturation of the minority.

There appear to be two opposed aspects in regard to acculturation of the Japanese Americans; that is, relinquishment of the traditional Japanese values on the one hand and retention on the other. This study will focus on the following questions: First, what sort of values have been relinquished or retained in three adult generations of the Japanese Americans? Second, if some are retained and others are relinquished, are those that are retained 
congruent with the American middle-class value systems and those that are relinquished incongruent? Finally, what intergenerational and intragenerational differences are observable in the pattern of retention and relinquishment of traditional Japanese values?

As will be fully discussed later on, the object of this study is to test what might be called the "acculturation-success" theory. The whole aspect of this theory is seen in Figure 1. Using Figure 1, most Nisei would fit to the cell I; that is, the category of "acculturatedtherefore-successful." Many Issei would fit to the cell III; that is, the category of "not-acculturated-butsuccessful." However, some Issei might be in the cell IV; that is, the category of "not-acculturated-and-notsuccessful." On the other hand, because the Sansei are still in their $20^{\prime} \mathrm{s}$ and $30^{\prime} \mathrm{s}$, it would be predicted that most of them are in the cell II; that is, the category of "acculturated-but-not-yet-successful."

Acculturation

Acculturated

Not Acculturated

Figure 1. Four Dimensions of the AcculturationSuccess Theory.

Success

Successful Not Successful

\begin{tabular}{|c|c|}
\hline I & II \\
III & IV \\
\hline
\end{tabular}


It is also hypothesized that there are four ideal types of the value system of the Japanese Americans. That is to say, there are: 1) those who have retained Japanese values and have adopted American values, 2) those who have retained Japanese values and have spurned American values, 3) those who have relinquished Japanese values and have adopted American values, and 4) those who have relinquished Japanese values and have spurned American values (Figure 2). People who have the characteristics of the cell III are predicted to be more successful than people who have the characteristics of the cell I, II and IV.

\section{Japanese Values} $\underline{\text { American Values }}$

Adopt

Spurn

Retain

Relinquish

\begin{tabular}{|c|c|}
\hline I & II \\
III & IV \\
\hline
\end{tabular}

Figure 2. Four Dimensions of the Value System of the Japanese Americans.

Concerning the relationship between the retentionrelinquishment pattern of Japanese values and success, further hypotheses can be derived. Within each generation:

1) Those who have retained traditional Japanese values which are congruent with the dominant American value system are more likely to be successful than those who have not.

2) Those who have relinquished traditional Japanese values which are congruent with the dominant 
American value system are less likely to be successful than those who have not.

3) Those who have retained traditional Japanese values which are incongruent with the dominant American value system are less likely to be successful than those who have not.

4) Those who have relinquished traditional Japanese values which are incongruent with the dominant American value system are more likely to be successful than those who have not.

In regard to these four aspects, it is hypothesized that these patterns would be observed 1) among the three generations, and 2) within each generation.

Thus, this study will be an intergenerational and intragenerational analysis. Further, the reasons for acculturation will also be considered. Finally, some implications of the future direction of the Japanese Americans as a minority in American society will be discussed. 


\section{REFERENCES FOR CHAPTER I}

Bonacich, Edna

1973 "A Theory of Middleman Minorities." American Sociological Review 38 (October): 547-59.

Caudill, William

1952 "Japanese-American Personality and Acculturation." Genetic Psychology Monographs 45: 3-102.

Cohen, Albert $\mathrm{K}$.

1955 Delinquent Boys: The Culture of the Gang. Glencoe, Illinois: The Free Press.

Kitano, Harry H. L.

1976a Japanese Americans: The Evolution of a Subculture. Englewood Cliffs, New Jersey: Prentice-Hall, Inc. Second Edition.

1976b "Japanese Americans: The Development of a Middleman Minority." In Norris Hundley, Jr., ed., The Asian Americans: The Historical Experience. Santa Barbara, California: CIio Press.

Hraba, Joseph

1979 American Ethnicity. Itasca, Illinois: F. E. Peacock Pubiishers, Inc.

Petersen, William

1966 "Success Story, Japanese-American Style." The New York Times Magazine (January 9): $20-43$.

1971 Japanese Americans: Oppression and Success. New York: Random House, Inc.

Schwartz, Audrey J.

1971 "The Culturally Advantaged: A Study of Japanese-American Pupils." Sociology and Social Research 55 (Summer): $341-51$.

U. S. Department of Commerce, Bureau of Census 1973 "Japanese, Chinese, and Filipinos in the United States." 1970 Census of Population. Washington, D. C.: Government Printing Office. 
1976 Statistical Abstract of the United States: 1976. Washington, D. C.: Government Printing Office.

Williams, Jr., Robin M.

1951 Ámerican Society: A Sociological Interpretation. New York: Alfred A. Knopf, Inc. The Third Edition in 1970 . 


\section{CHAPTER II}

\section{THE HISTORICAL BACKGROUND}

\section{How Did It Start?}

The large scale Japanese immigration to the mainland United States did not begin until almost the end of the nineteenth century. This was because of the rigorous enforcement of travel prohibition for Japanese during the Tokugawa regime (1603-1867). In addition, the prohibition against leaving the country was continued for some time although the new Meiji government was to break down the heritages from the feudalistic Tokugawa Shogunate. Therefore, prior to the repeal of the prohibition against laborers going abroad most of the Japanese in the United States were students (Hosokawa, 1969: 37).

After labor emigration was legalized in 1884 by the Meiji government, people started emigrating gradually, primarily to Hawai, then to mainland America. McWilliams (1944: 74) asserted they came to the United States for purely economic reasons and not as refugees in quest of religious or political freedom. Their socio-economic background was reported to be lower farming class (Kitano, 1976:11). 
The farming class in Japan's rigid hierarchical society at that time was a lower status group. However, most of the members of the class had the equivalence of an eighth-grade education (Edward, 1934: 185-7). Moreover, as an immigrant group, they were exceptionally hard workers, habituated by experience to the most strenuous physical labor (McWilliams, 1944: 35). Regarding the causes of their emigration, McWilliams (1944: 74) has written:

The immigrants who came to Hawaii and the West Coast were "birds of passage": not one in a thousand intended to remain. They planned on returning to Japan as soon as they had accumulated a nest egg.

There is another significant factor with respect to the background of Japanese emigration; that is, the overcrowding of the home population. Owing to the rigorous social structure of feudalism during the Tokugawa regime, Japan's population could not swell beyond a certain number - it remained around twenty-six million (Ichihashi, 1932: 378-91). Malthusian factors, such as pestilence and famine, as well as artifical means of birth control prevented the nation from excessive expansion of the population. However, the population started to expand at a tremendous rate when the feudalistic Tokugawa regime was replaced by the new Meiji government, whose political and social policies were much more liberal. The advent of occidental enlightment went far to improve the economic 
conditions of the country and, hence, the living conditions. Consequently, the rapid multiplication of people became a social problem. In the period between 1872 and 1927 , the population increased from thirty-three million to sixtyfour million (Ibid., 380). As a result, emigration was promoted by the government as well as by private organizations. Destinations were sought in such countries as Hawai, the United States, China, Korea, Brazil and Canada.

TABLE I

JAPANESE POPULATION IN THE MAINLAND UNITED STATES

\begin{tabular}{lrrr}
\hline Census Year & Number & Decade & $\begin{array}{c}\text { Percentage } \\
\text { Rate of } \\
\text { Increase }\end{array}$ \\
1970 & 373,987 & $1960-70$ & 43.4 \\
1960 & 260,887 & $1950-60$ & 83.3 \\
1950 & 141,768 & $1940-50$ & 11.6 \\
1940 & 126,947 & $1930-40$ & -13.1 \\
1930 & 138,834 & $1920-30$ & 25.1 \\
1920 & 111,010 & $1910-20$ & 53.8 \\
1910 & 72,157 & $1900-10$ & 196.6 \\
1900 & 24,326 & $1890-1900$ & $1,093.0$ \\
1890 & 2,039 & $1880-90$ & $1,227.7$ \\
1880 & 148 & $1870-80$ & 169.1 \\
1870 & 55 & $1860-70$ & \\
1860 & 0 & $1850-60$ & \\
\hline
\end{tabular}

From U. S. Department of Commerce, Bureau of the Census, Population Characteristics By Race of Non-White Population. Mainland figures were obtained by subtracting Japanese population in Hawaii.

With regard to the emigration to the United States, the population of Americans of Japanese descent in the main1 and United States has been increasing continuously as 
Table I shows. The only exception occurred during 193040 decade when the number of Japanese returning to the homeland exceeded the number of new immigrants. By 1970, the Japanese population in the mainland America had reached 370,000 .

However, it was sometimes noted that the Japanese were "incapable of assimilation" (McWilliams, op. cit.: 73) presumably because of the somewhat slower rate of assimilation of Japanese immigrants in America in comparison with some other immigrant groups. Certain behavioral patterns of Japanese immigrants appeared incomprehensible to the non-Japanese. This is easily explained by a cultural heritage which was radically different from the Occidental traditions. For instance, traditionally, Japanese place less emphasis on individuality; on the other hand, they place great importance on group superiority. This idea, which was derived from Shinto philosophy of wa or harmony, has been fully established in Japan for hundreds of years. Hence, the behavior of Japanese immigrants might be somewhat "curious, mysterious and inscrutable" to many nonJapanese in America who emphasize rugged individuality.

Nature of the Immigrants

As Kitano (1976: 51) pointed out, much early Issei behavior appeared to reflect the behavior patterns commonly associated with the lower class of the hierarchical structure of Japanese society in the late eighteenth and the early 
nineteenth century. Recognition of this factor will be helpful in comprehending the Issei's pattern of achievement orientation to the middle class.

"It is seldom," said McWilliams (1944: 73), "that a first-generation foreign-born group has become thoroughly assimilated, particularly where sharp cultural, Iinguistic, and racial differences are involved." In particular, cultural luggage from their homeland was an invisible, yet crucial obstacle for the Issei immigrants to achieve smooth assimilation.

There is another obstacle to assimilation; that is, rejection of interracial marriage. In the early twentieth century, within a short period of time, spouses were chosen by and for the male immigrants - most of them were unmarried - from the pictures of bride-candidates who were living in Japan. The practice of marrying "picture brides" continued until 1920 when the Japanese government, under pressure from the American government, ceased to issue passports to "picture brides." In 1920, the sex ratio (the number of males per 100 females) was 190 , whereas it was 2,370 in 1900 (Marden and Meyer, 1978: 300).

Although marital preference of the Japanese immigrants remained in-group, they endeavored to adapt themselves to the American culture. Their strategy for adaptation was to be like a stream - - "they have followed the contours of the land, followed the lines of least 
resistence, avoided direct confrontation, and developed at their own pace, always shaped by the external realities of the larger society" (Kitano, 1976: 30). Consequently, it has often been noted, "Scratch a Japanese American and find a white Anglo-Saxon Protestant."

The Japanese Americans are claimed to have achieved successful acculturation. The reason appears to be derived from the cultural compatibility between Japanese Americans and white Americans. Inasmuch as culture is an integral element of human social interaction (Parsons 1951: 15), it is imperative to examine cultural compatibility as we 11 as incompatibility between these two cultures. Unlike other immigrant groups from other countries, generalizations about the cultural patterns of the firstgeneration Japanese immigrants may be possible because Japanese immigrants came from the southern prefectures such as Hiroshima, Okayama and Yamaguchi (Hosokawa, op. cit.: 37). The value system of those districts is presumed to have been homogeneous.

The character, or personality, of the immigrants from Japan has been carefully scrutinized. Above all, Benedict's The Chrysanthemum and the Sword: Patterns of Japanese Culture (1946) is an excellent introduction to the value system of the first-generation Japanese immigrants. Despite Benedict's attempt to reveal the development patterns of the ideology of the Japanese, she had 
never had real contact with the Japanese in Japan. Instead, data were gathered from the Issei, who she assumed were representative of Japan's national character. Namely, she attempted to elicit the standardized patterns of Japanese behavior by the data from the Japanese in America, the Issei. Therefore, her pioneering study focusing on patterns of Japanese culture seems to be valid with respect to the values shared by the Issei.

Japanese in Japan and Japanese in America

In regard to the differences between the Japanese in Japan and the Japanese in the United States, Kitano (1969: $77-8)$ has written that:

The differences between the Japanese in the two cultures can be attributed to many sources. One of the most important deals with majorityminority status -- the Japanese Americans living as a small group within a white majority have constantly adapted to a weaker position through servility, conformity, conservatism and a willingness to please.

Another plausible explanation for the differences relates to the relative isolation of the Japanese in America. Because of this isolation, their values, representing the Meiji Japanese era, have remained relatively intact and unchanged, while the people in Japan have seen rather dramatic changes.1 (Underlined by the writer).

As far as studies about Japanese culture in the homeland are concerned, Western writers have sometimes over-

$1_{\text {This }}$ is a quotation from the first edition of Kitano's Japanese Americans: The Evolution of a Subculture (1969). The paragraph entitled "The Differences Between Japanese in Japan and the United States," which contains this quotation, has been eliminated from the second edition. 
emphasized the "traditional" aspects of Japanese culture and underestimated the great changes which were taking place. Writers, such as Benedict and Dore, have often been criticized for placing too much emphasis on the hierarchical structure of interpersonal relations, the importance of obligations over human nature, and the priority of the family over the individuals (Benedict, 1946; Dore, 1958). Such studies have not recognized the rapid social changes in Japan since the Meiji Restoration of 1868. Namely, a firm generalization of one decade is likely to become obsolete in the next decade and it may fall into oblivion in the one after. The prominent features of the Japanese way of life have shown remarkable difference between, for instance, the 1930's and 40's, or the $1950^{\prime} \mathrm{s}$ and $70^{\prime} \mathrm{s}$. A great variety of elements of Japanese culture traits are subject to constant change. Reischauer (1977: 124) writes:

Contemporary Japanese are no more bound by the patterns of feudal warriors, Tokugawa samurai bureaucrats, or prewar militarists than Swedes are bound by viking traditions or early modern military conquests, Germans by their premodern political disunion or their more recent Nazi experience, or Americans by their Puritan heritage or traditions of isolationism.

Obliteration of Japanese traditions through cultural de-institutionalization was particularly salient in the processes of demilitarization and democratization which occurred after Japan's defeat in World War II. Consequently, the standard of their conduct has been changing 
rapidly. A given value pattern merely has transitory validity. Because the Japanese Americans do not have this experience as well as their relative insulation from the dominant American community, their value system still contains the values of the Meiji era when the most Issei emigrated from Japan to America.

Because people in Japan have experienced rapid social changes, the society to which they belong is as a result considerably complex and divergent. Despite the small size of the land, contemporary Japan is a complex society containing different types of value systems. Therefore, as Reischauer (1977: 124) states, "the roughly 115 million Japanese display great variations of attitudes and ways of life by age group and according to their diverse roles in society." Thus, the traditional Japanese culture which many Issei have remembered and practiced is no longer identical with the contemporary Japanese culture. Therefore, when the Issei visit their home town in Japan after a long period of absence, most of them find it different or alien from the image they were holding.

Racism in American Society

The Issei faced a variety of discrimination by the whites when they immigrated. The discrimination they experienced was a manifestation of American racism. As was mentioned in the previous chapter, racism and related group-superiority themes have been two of the major value 
orientations in American society. The Japanese immigrants had to develop a special strategy to protect themselves from American racism which rejected Japanese immigration to the United States. What sort of nature does American racism have and how has it affected the assimilation pattern of the Japanese immigrants and their descendants?

Hodge, Struckmann and Trost (1975) argued that Western culture underlies a strong sense of dualism; that is to say, there is an institutionalized value among the Western societies, including America, that the universe is divided into objectively existing and recognizable forces of "good and evil" which are necessarily in conflict. With regard to the notion of dualism and group oppression, Hodge states:

Because of his Dualist presuppositions, the traditional Westerner assumes that what is not Good is Bad or Evil. The not-Good includes all behavior not predetermined by or contained within prescribed 1 aw and all behavior guided primarily by feeling or emotion. The not-Good also includes spontaneous emotional expressiveness, intimacy with nature, and bodily urges and instincts. These not-Good qualities are considered to be "nonrational." These are the qualities which are to be controlled by the Good, as the Good is supposed to control the not-Good. (Hodge, et a 1, 1975: 235).

Thus, the combination of rationalism and dualism, both of which are the major value orientations in American society, has produced racism and related group-superiority themes as two of the major value orientations in the United States. 
It has been believed that "inferior" cultures are to be controlled by the more "rational" culture. Many examples of the practice of this "logic" are found in the history of America. The Japanese Americans were examples of victims of this "logic," culminating in their experiences of relegation to internment camps during World War II. Hodge, et al $(1975: 236)$ assert that, once the nonWestern people are identified by race, they are forced into the bottom of the hierarchical structures of American society. Consequently, there have been hostilities against non-Western immigrants. Among them included the Chinese, Korean and Japanese.

With respect to anti-Japanese movements, the first overt act occurred in San Francisco in March, 1900. The areas of the city where both the Chinese and the Japanese were living were quarantined by the mayor without any reasonable explanation. In response, the Japanese organized the Japanese Association of America to protest against the racial discriminatory movement. With this event as a start, the anti-Japanese campaign gradually spread, first in California and later throughout the nation. "Japanophobia" never disappeared until Japan's defeat in World War II although there were minor changes in the attitude toward the Japanese as international situations changed.2

${ }^{2}$ See, for example, McWilliams (1944), Bosworth (1967), Myer (1971), or Chuman (1976). The 1iterature offers various views regarding the history of anti-Japanese movements. 
Discrimination was blatantly reflected in the legislation that attempted to exclude the Japanese population. There were such items in anti-Japanese legislation as: forbidding Japanese the use or ownership of power engines; forbidding Japanese to employ white girls; making Japanese inheritance of land illegal, and raising the standard fishing license fee of ten dollars per year to one hundred dollars for Orientals (Kitano, 1976: 28).

Above all, the anti-Japanese land laws (the Alien Land Laws) were a harsh reality for the Japanese immigrants because these laws prohibited them from owning land. Many of the early immigrants were engaged in various forms. of farm labor for most of them had experience in and respect for farming. The white farmers were afraid of the possibility that Japanese farmers might take over the agricultural market. Consequently, this fear influences the state legislatures of various states to take action against Japanese immigrants.

The first anti-Japanese 1 and 1 aw was enacted in California in 1913. The purpose of this bill was to drive the Japanese out of agriculture, and perhaps out of California. Later on, the anti-Japanese land legislation spread to other states: Arizona in 1917, Louisiana in 1921, New Mexico in 1922, Idaho, Montana and Oregon in 1923, Kansas in 1935, and Arkansas, Utah and Wyoming in 1943. Attorney General Webb made a speech in 1913 
concerning the nature of the California Alien Land Bill in which he stated:

The fundamental basis of all legislation ... has been, and is, race undesirability. It seeks to limit their presence by curtailing their privileges which they may enjoy here, for they will not come in large numbers and long abide with us if they may not acquire land. And it seeks to limit the numbers who will come by limiting the opportunities for their activity here when they arrive (Gulick, 1914: 189).

The Alien Land Law of 1913 was amended in 1920, in an act "designed to prevent the Issei from acting as guardians for the property of a native-born minor if the property could not be held legally by the alien himself" (Kitano, 1976: 69).

The consistency and intensity of anti-Japanese hostility were persistent. However, other immigrant groups have also experienced discrimination similar in kind and intensity to that experienced by the Japanese immigrants, due to white racism. In other words, minority groups have been "equally" oppressed by the white majority.

The Current Trend in the Community of the Japanese Americans

At first, backgrounds of the Japanese immigrants were homogeneous with respect to their age structure, sex, regions of origin, social class, length of completed formal education. However, as time passed, some heterogeneity has appeared within the community of the Japanese Americans. As Kitano (1976: 9-10) argued:

The convenient division of the present Japanese population into relatively homogeneous Issei, Nisei, 
and Sansei groups is complicated by the presence of the Kibei (Japanese educated Nisei); the postwar influx of Japanese war brides; the arrival of many new Issei immigrants beginning in the 1950's; the entrance of Japanese businessmen, tourists, and sojourning students; and a continuous stream of Japanese from Hawaii, who are not necessarily homogeneous in education, generation, or other characteristics.

Characteristics of these subgroups are divergent. Consequently, a pluralistic structure has emerged. Therefore, when considering the Japanese acculturative process, it should not be forgotten that structural pluralism is now a widespread phenomenon in the community of the Japanese Americans. 
REFERENCES FOR CHAPTER II

Benedict, Ruth

1946 The Chrysanthemum and the Sword: Patterns of Japanese Culture. New York: New American Library.

Bosworth, Allan R.

1967 America's Concentration Camps. New York: W. W. Norton and Company.

Chuman, Frank F.

1976 The Bamboo People: The Law and Japanese Americans. Del Mar, California: Publisher's Inc.

Dore, Ronald P.

1958 City Life in Japan: A Study of a Tokyo Ward. Berkeley and Los Angeles, California: University of California Press.

Gulick, S. L.

1914 The American Japanese Problem. New York:

Charles Scribner's Sons.

Hodge, John L., Donald K. Struckmann and Lynn D. Trost

1975 Cultural Bases of Racism and Group Oppression:

An Examination of Traditional "Western" Concepts, Values and Institutional Structures Which Support Racism, Sexism and Elitism. Berkeley, California: Two Riders Press.

Hosokawa, Bill

1969 Nisei: The Quiet Americans. New York: William Morrow and Company, Inc.

Ichihashi, Yamato

1932 Japanese in the United States: A Critical Study of the Problems of the Japanese Immigrants and Their Children. Stanford University, California: Stanford University Press.

Kitano, Harry H. L.

1969 Japanese Americans: The Evolution of a SubPrentice-Hall, Inc. Second Edition in 1976. 
Marden, Charles F. and Gladys Meyer

1978 Minorities in American Society. New York:

D. VanNostrand Company. Fifth Edition.

McWilliams, Carey

1944 Prejudice: Japanese-Americans, Symbol of Racial Intolerance. Boston, Massachusetts : Little, Brown and Company.

Myer, Dillon S.

1971 Uprooted Americans: Japanese Americans and the War Relocation Authority During World War II. Tucson, Arizona: University of Arizona Press.

Parsons, Talcott

1951 The Social System. New York: The Free Press. Paperback Edition.

Reischauer, Edwin 0.

1977 The Japanese. Cambridge, Massachusetts: Harvard University Press.

Strong, Jr., Edward K.

1934 The Second-Generation Japanese Problem. Stanford University, California: Stanford University Press. 
CHAPTER III

CONCEPTUALIZATION OF THE STUDY

The Notion of Values

Orientation for the study of values has come from the fields of anthropology and sociology (K1uckhohn, 1951; Albert, 1953; Kluckhohn and Strodtbeck, 1961; Parsons and Shils, 1951; Williams, 1951; among others). In the field of sociology, the study of values sometimes has been regarded as the study of the subjective because of the unobservable nature of values. However, objective and scientific aspects of the study of values have been developed beginning with The Polish Peasant in Europe and America, a remarkable pioneering effort by Thomas and Znaniecki (1918). As a result, the study of values is now considered to deal with the "social facts" that are suitable objects for a sociological interpretation. Moreover, analysis of values is an important approach for the study of behavioral patterns of a particular group of people.

Values are defined by Parsons (1970: 158) as "patterned conceptions of qualities of meaning of the objects of human experiences; by virtue of these 
qualities, the objects are considered desirable for the evaluating persons." Williams (1970: 442) defines values as "those conceptions of desirable state of affairs that are utilized in selective conduct as criteria for preference or choice or as justifications for proposed or actual behavior."

Based upon these definitions, one could consider values as those standards by which our behavior is determined. However, it should be noted that values are nur tured by the individuals through the process of socialization; in other words, in order for values to be fixed, they have to be internalized by the individuals.

Values are internalized in various social settings. Parental discipline and formal education appear to be two of the major sources of value internalization. Both are significant factors in value internalization; and those factors seem to be supplementary. Once internalized, values would play an important role in determining one's behavior. Parsons and Shils (1951) have argued that internalization of values is a function of the fundamental role structure within a society, and it creates normative integration among the individuals. Moreover, according to Parsons and Bales (1955), society and individual are both well organized by the medium of values. Values are "institutionalized" within a society, while they are "internalized" by an individual. Thuse, values are integral parts 
of social character as we 11 as individual character (i. e., personality). Values would determine the destination of society and/or individual once they are institutionalized and/or internalized. A question arises: What is the mechanism of value internalization? In the following sections of this chapter, the writer addresses this question, dealing with Japanese Americans as a case.

Japanese Immigrants and the Notion of Reference Groups

People act in a social frame of reference held by the groups to which they belong. However, there is also another aspect of human behavior; that is, people frequently orient themselves to groups other than their own in shaping their behavior and evaluation. ${ }^{1}$ This factor seems to be a crucial concept in the study of acculturation of certain immigrant groups in the United States.

Merton (1968: 384) has pointed out that the consideration of "different reference groups for different norms and values" has become an important focus of sociological attention. The notion of reference groups has thus been developed to refer to those groups or social categories which are especially significant to an individual in helping to define his/her values, beliefs and behavior. The individual does not have to be a member of his/her reference group; namely his/her reference group is the

${ }^{1}$ Above all agruments, see Robert K. Merton, Social Theory and Social Structure (1968), Chapter XI. 
group he/she looks up to and intends to conform. Therefore, it is possible that first-generation Japanese immigrants have relinquished the values and customs of their own country in order to conform to the values and customs of those Americans whom they selected as their reference group. The next question is: Who were "those Americans" whom Japanese immigrants chose as their "model"? Did Japanese immigrants really select a certain part of American society as their reference group?

As mentioned in Chapter II, the Japanese immigrants who came to the United States planned to return to Japan as soon as they had accumulated a "fortune." Not one in a thousand intended to remain; instead, they intended to return home loaded with a fortune and with honors. This fact might lead us to a conclusion that the Japanese immigrants did not spontaneously conform to the norms of any group in the dominant American society. Instead, it is more likely that they have conformed to some ethnic social organizations in the community of Japanese settlers. If this assumption is correct, the Japanese immigrants were as a result insulating themselves from the dominant group in the United States. The prefectural associations, Kenjinkai ( $\underline{k e n}=p r e f e c t u r e ; ~ \underline{j i n=p e o p l e ; ~} \underline{k a i=a s s o c i a t i o n), ~ a r e ~ e x c e l l e n t ~}$ examples of social organizations among the Japanese settlers in America to which most Japanese had a sense of attachment. Light (1972: 62) has pointed out that ken-consciousness was 
characteristic only of overseas Japanese. He writes:

The manifest purpose of the kenjinkai were social and benevolent. ... T T] he kenjinkai also played a leading role in overseeing the social and economic welfare of the immigrants.... Prefectural contacts were critical sources of influence in business and politics. Kenjinkai provided direct welfare assistance to destitute or needy members, buried the indigent, and paid medical bills. Because of these varied prefectural services, Japanese thought that membership in a large kai was a distinct advantage (Light, 1972: 62-3).

Almost all the Japanese immigrants were eligible for membership in one of the Kenjinkai. Solidarity among the members of a Kenjinkai was very strong. Because of the tight bond among people of the same prefectural origins, "Japanese employees often were more loyal to their employers than to the labor movement, and Japanese businessmen [and farmers] with access to cheap and dependable ethnic labor had an important edge over their competitors (Hraba, 1979: 324). With regard to economic functions of the Kenjinkai, Hraba has written:

Family and regional ties reinforced the economic interdependence between Japanese businessmen and farmers and their employees and field hands. Because Japanese businessmen typically hired members of their own family or Kenjin, in most cases the relationship between employer and employee was more than simply economic; it was one of blood and regional loyalty as well. Moral obligations to family and ken tied employers and employees to one another, checking the tendency in a purely economic exchange for each party to seek only self-interest. The mutual loyalty between Japanese capital and labor was further strengthened in the common practice of Japanese employers setting up their employees in businesses of their own after an apprenticeship had been served (Hraba, 1979: 323).

Kenjinkai thus played a critical role in many respects 
protecting its members from prejudice and discrimination. It was a refuge for the Japanese immigrants. Therefore, the existence of such an ethnic organization was a crucial hindrance for Issei assimilation into American society. Accordingly, based upon the arguments so far, it would be hypothesized that first-generation Japanese immigrants did not have any "reference groups" other than those Japanese groups to which they belonged. In other words, there were no particular Americans whom the Japanese immigrants chose as their "model-to-be." In Riesman's terminology, the immigrants from Japan were not otherdirected people. ${ }^{2}$ Rather, the Issei can be classified as inner-directed people, with some characteristics of tradition-direction. Their values, which were internalized in the early stage of their lives in Japan, remained as guideposts for behavior throughout their lives, even after they emigrated from Japan to the United States. Next, let us examine the personality structure of Japanese immigrants.

Personality Structure of Japanese Immigrants

In regard to the definition of tradition-direction, Riesman writes:

The society of high growth potential develops in its typical members a social character whose conformity is insured by their tendency to follow

2 David Riesman, with Nathan Glazer and Reuel Denney, has developed the concepts of tradition-, inner- and otherdirection in his book entitled The Lonely Crowd: A Study of the Changing American Character (1950). 
tradition: these I shall term tradition-directed people and society in which they live a society dependent on tradition-direction (Riesman, 1961: 8).

Also, with regard to inner-direction, he writes:

The society of transitional population growth develops in its typical members a social character whose conformity is insured by their tendency to acquire early in life an internalized set of goals. These I shall term inner-directed people and the society in which they live a society dependent on inner-direction (LoC. Cit.).

The Japanese immigrants appear to have the characteristics of both tradition-direction and inner-direction. It would be hypothesized that inner-direction was nurtured in Japanese society, and tradition-direction in American society.

According to Riesman, inner-direction is generated in a society which is characterized by:

increased personal mobility, by a rapid accumulation of capital (teamed with devastating technological shifts), and by an almost constant expansion: intensive expansion in the production of goods and people, and extensive expansion in exploration, colonization, and imperialism (Ibid: 14).

Aspects of Japanese society in the Meiji (1868-1911), Taisho (1912-25) and Showa (1926-present) eras, until the defeat in World War II, fit exactly the characteristics that Riesman has described. The primary interest of Japanese society since the end of feudalistic Tokugawa regime was consistently to expand national power. Every possible means was used to attain this national expansion policy. As a result, this promoted the rapid industrialization as 
well as militarization. The national population increased at a tremendous rate as was mentioned in Chapter II. Moreover, as the national power of imperial Japan increased, the number of Japanses emigrants also increased (see Table I in Chapter II).

Riesman, using the metaphor of the "gyroscope," argued that the internalized values, once they are set in place by the parents and other authorities, keep the inner-directed person "on course" even when his/her parents and other authorities no longer dictate his/her behavior. $\mathrm{He} / \mathrm{she}$ would decide what to do throughout life on the basis of those internalized values. If the Issei were inner-directed people, Riesman's theory can well explain the phenomenon that traditional Japanese culture has been retained more strongly among the Issei than among the Japanese in contemporary Japan. (Isolation provides another basis for this phenomenon, as was discussed in the previous chapter.)

Riesman provided further analysis regarding the characteristics of the inner-directed people by stating that "he can cooperate with others in action while maintaining the right of private judgement" (Ibid: 251). One of the salient behavioral traits of the Issei, which might be called "double loyalty," can be explained by this argument. If Riesman's hypothesis is correct, the innerdirected Issei were able to manage a delicate balance 
between those two aspects, which Riesman calls "the demands upon him of his goal in life and the buffeting of his external environment" (Ibid: 16). Consequently, it is hypothesized that the first-generation Japanese immigrants were "autonomous inner-directed people," those who "possessed clear-cut, internalized goals and were disciplined for stern encounters with a changing world" (Ibid: 290). As a matter of fact, Japanese immigrants were a group of people who neither became lost to the demands of the American culture nor were broken by them.

Reischauer, in describing the demands of the American culture toward the Japanese immigrants, has stated that:

No immigrant group encountered higher walls of prejudice and discrimination than did the Japanese - - the denial [by] racist. groups of the right to naturalization, the denial in the areas where they largely lived of the right to own land or enter certain professions, and eventually complete exclusion (Reischauer, 1969: xi).

Consequently, immigrants appear to have retained a strong and assertive sense of Japanese identity even though they have long been isolated from their parents and other authorities from whom they internalized the traditional Japanese values. In this very specific sense, it is hypothesized that the Japanese immigrants nurtured tradition-directed personality besides their inner-directed personality. Their sense of loyalty to their own community (e.g., Kenjinkai) is an excellent example for their traditiondirectedness. 
Based upon the discussion thus far presented, one could argue that the Japanese immigrants have embraced the values that are the mixture of tradition- and innerdirection. Now, let the discussion flow to the next topic - the discussion of the traditional Japanese value system. What characteristics did it have?

Foundations of the Traditional Japanese Value System

As was documented in Table I, the rapid increase of the Japanese population in the mainland United States occurred during the late nineteenth century and early twentieth century. This period roughly corresponds with the Meiji Imperial era, from 1868 to 1912. Therefore, it is assumed that the traditional Japanese values the Issei embraced were based upon so-called "Meiji ideology." One should know the historical background of the political transition from the Tokugawa regime to the Meiji regime to understand the nature of the Meiji ideology. This political transition occurred in the middle of the nineteenth century. With regard to the final phase of the Tokugawa regime, Reischauer wrote:

While the general political pattern remained rigidly unchanging, beneath the surface there were great dynamic tensions between Confucian and feudal values and between economic growth and a frozen class society. Japan, far from becoming an immobile society in its isolation, remained capable of great change, as it was to demonstrate brilliantly in the second half of the nineteenth century (Reischauer, 1977: 77 ) . 
Attempted rebellions did not occur until the first half of the nineteenth century despite those conflicts. People's consciousness was severely suppressed in the Shogunate's continuous endeavors to maintain the rigid hierarchy in society. Confucianism, which stresses the hierarchical nature of society, was strongly advocated to reinforce the feudalistic orders of Tokugawa society. On the other hand, Christianity, which stresses equality or emancipation of suppressed people, was strictly prohibited by the Shogunate. The Shogunate adopted the national seclusion policy partly in order to exterminate the Christians. This policy eventually lasted more than two centuries. However, the invention of steam navigation enabled Western military powers to sail across the Pacific Ocean. Various Western countries tried to obtain the use of the Japanese ports by surrounding the islands of Japan with their warships. Those warships overpowered the nation. Consequently, fear of being attacked was generated among the Tokugawa samurai bureaucrats.

This fear reached its zenith when the Shogunate was forced by the American navy in 1853 to abolish the 1ongtime policy of national seclusion. Most of the nation was against opening the country; nevertheless, the Shogunate signed many treaties with Western countries. As a result, there was a growing opinion that "in order to meet the foreign menace, the nation would have to pull itself 
together more effectively around the emperor, as the legitimate symbol of unity" (Reischauer, 1977: 79-80). Subsequently, young radical samurai bureaucrats became active under the slogan of "Revere the emperor and oust the barbarians!"

This slogan was not intended to be either an attack on the Shogunate nor a call for imperial restoration. Concerning this point, Varley wrote:

"Revere the Emperor!" was a Confucian-Shinto inspired reminder of the ethical obligations within Japan's hierarchically ordered society: by revering the emperor, subjects would automatically be loyal to the shogun (to whom the emperor had delegated governing powers) and, at a lower level, would be obedient to their immediate superiors. "Oust the Barbarians!", on the other hand, was an injunction to the Shogunate to strengthen defenses against the threat of foreign aggression (Varley, 1973: $195-60$ ).

Recognizing the critical situation, the Shogunate finally accepted to restore the emperor system. Thus, the Tokugawa regime ended after its reign of prosperity over more than two and a half centuries.

Before the Meiji government was established, Confucianism and Buddhism had long been the bases of the nation's value systems. Both Confucianism and Buddhism had their heyday during the Tokugawa period. In particular, Confucianism, as a philosophy rather than religion, was strongly supported and advocated by the Tokugawa Shogunate because Confucianism stresses social equilibrium, especially a rigid hierarchical order of society. Confucianism fitted 
the policies which the Tokugawa Shogunate embraced; in other words, Confucianism was a means to maintain social order during the Tokugawa regime from 1603 to 1867. However, Shinto was highlightened instead of Confucianism with the establishment of the Meiji regime in 1868. Shinto was a primitive religion which stressed the animistic worship of natural phenomena until it was strengthened by the concept of imperialism. Shinto became a significant part of Meiji ideology due to this reinforcement which acknowledged the position of the emperor as sacred. Furthermore, the nation's new ideology nurtured the growth of Japan's nationalism and militarism until the official announcement by the Emperor Showa of the defeat in the Second World War.

The nature of Meiji ideology was thus highly artificial; however, the government was extremely careful in developing this ideology. That is to say, the government did not totally spurn Confucianism and Buddhism. Rather, the government tried to synthesize Confucianism and Buddhism with New Shinto. This endeavor was crystallized in the new Constitution promulgated in 1881. Thus, Meiji ideology, a selective combination of Shinto and Confucianism and Buddhism, was internalized by the nation as the Meiji Constitution was institutionalized.

Meiji ideology was considered to be a manifestation of patriotism. It was an essential part of the Japanese 
value system. Besides, Meiji ideology was homogenous due to thorough "thought control" through the education system. Consequently, it generated a strong national norm of patriotism.

The Emperor was appointed in the Constitution as an absolute and charismatic leader of the nation. A Shinto idea was used as the rationale for this argument; namely, the Emperor Meiji was the direct descendant of Gods who created Japan. This mythology was reinforced by the ethics of Confucianism and Buddhism.

From the arena of Confucianism, the idea of family unity was adopted. That is to say, Meiji ideology emphasizes that all the Japanese people are to be unified under the Emperor as an absolute patriarch. The rationale for this was the fact that the Emperor famly had maintained its family line for more than two thousand years. Thus, the appointment of the Emperor as an absolute monarch promoted ethnic authenticity within the nation.

From the beliefs of Buddhism, on the other hand, the idea of an ever lasting soul was adopted. This became the rationale for perpetual nature of the state, that is, imperialism. Consequent1y, rapid development of the state was stressed by the government focusing on industrialization and militarization.

It should also be noted that the government put great importance on education. Education was emphasized 
for the development of the "sound" self by understanding the meanings of being born as a Japanese. In particular, moral education was emphasized. Emphasized values include: spiritual and physical discipline, benevolence, justice, loyalty and filial duty. The endeavor by the government to institutionalize those values reached its climax when the Meiji Emperor promulgated the Imperial Rescript on Education in 1890.3

Thus, the nature of Meiji ideology, which has been the basis of the Issei's value system, was highly patriotic, imperialistic and moralistic. In addition, there was another remarkable aspect of Meiji ideology, that was its homogeneity. As was mentioned, homogeneous national ideology was institutionalized through the educational system. Consequently, Meiji ideology was strongly internalized by the nation, its members including those who emigrated to the United States later on. A question arises: In the subsequent generations of Japanese Americans, what kind of value system has been developed on the foundation of the Meiji ideology which was brought to the United States by the Issei? Or, how has the Issei's value system been modified by their descendants?

The Value Systems of the Japanese Americans

With regard to the value systems in the community of

3 The translation of the Imperial Rescript on Education of 1890 is seen in Appendix $K$. 
the Japanese Americans, which mainly consists of three adult generations, a number of studies have been conducted since World War II. Those endeavors appear to have the same goal, to give cognitive explanation to the clash of traditional values shared by the Issei and modern values shared by the Sansei. Kitano has pointed out:

[A] 1though Japanese and Americans have differed in
the past in their collective and individualist ori-
entations, the collectivity orientation has dimin-
ished among Sansei and at present is similar to
that of Caucasian samples. Egoistic behavior and
the importance of self over others has developed to
such an extent that ... the Sansei held a more in-
dividualistic position than did the non-Japanese
American! Similarly, standards of discipline, pa-
ternalism, status distinction, and other parameters
of the "American" value system show that the Sansei
are for all practical purposes completely accultur-
ated (Kitano, 1976: 141). In other studies, intergenerational personality differences of the Japanese Americans have been studied from the perspective of acculturation. Caudill's study (1952) indicated that there was a logical consistency between the values and the adaptive mechanism of the Issei and Nisei. DeVos's study (1955) has shown that the direction of acculturation is toward the American norms. Iga (1966) has mentioned that acculturation of the Sansei has been so complete that "we cannot anticipate their return to traditional Japanese cultural interests" (Iga, Loc cit.). There are, however, reports from the opposite point of view. Arkoff (1959) and Arkoff, Meredith and Iwahara (1962, 1964) pointed out that there has been considerable 
retention of traditional Japanese values even among the Sansei. Meredith and Meredith (1966) reported that Sansei males are more humble, more conscientious, and more regulated by external realities than CaucasianAmerican males; at the same time, Sansei females are less emotionally stable, less independent, and less self-assured than Caucasian-American females. Petersen (1971: 232) has concluded that the Japanese-American community still has the "community allegience" and "nothing is done without fully considering its effect on 'the Japanese image." These two perspectives argue the value system of Japanese Americans from two different points of view. The first perspective attributes the cognitive explanations of the intergenerational personality differences preponderantly to social factors. Key concepts in this approach include "value systems," "social norms," "adaptive mechanisms," "acculturation." In contrast, the second perspective emphasizes the psychological factors in its explication of the intergenerational personality differences. Key concepts in this approach include "the Japanese image" and "cultural reminiscence of the third-generation people -- the grandson seeks to remember what the son wishes to forget."

This study pursues a sociological perspective in its analytical framework. Consequently, the second approach will not be considered in this study of intergenerational 
personality differences. Thus, in this study, acculturation as a cultural phenomenon would be discussed in sociological terms.

"Assimilation" and "Acculturation"

A firm definition should be given to the key concept of this study, acculturation. In particular, acculturation has to be recognized separately from assimilation. Assimilation is defined by Theodorson and Theodorson to be "both the one-way absorption of an individual or group into another group and the mutual absorption or blending of divergent cultures" (Theodorson and Theodorson, 1969: 17). On the other hand, acculturation is defined by them to be:

the modification of the culture of a group or an individual through contact with one or more other cultures and the acquiring or exchanging of culture traits (Ibid: 3 ).

Further distinctions between the terms are made by them:

Assimilation is similar to acculturation, in which a culture is modified through contact with one or more cultures, but assimilation involves the complete elimination of cultural differences and differentiating group identification (Ibid: 17).

In short, it can be stated that acculturation is a cultural phenomenon while assimilation is a social phenomenon.

Hraba (1979) emphasized the dual aspects of assimilation, that is, acculturation and integration. According to him, acculturation refers to the fusion of the culture of different groups; while integration refers to the fusion of groups in the sense that social interaction is no longer 
predicated upon one's racial or ethnic identity.

On the other hand, Gordon (1964: 71) has classified seven types of assimilation. They are:

1) Cultural or behavioral assimilation (or acculturation)

2) Structural assimilation

3) Marital assimilation

4) Identificational assimilation

5) Attitude receptional assimilation

6) Behavioral receptional assimilation

7) Civic assimilation

According to Gordon (1964: 77), cultural assimilation (or acculturation) is likely to be the first type of assimilation to occur when a minority group arrives on the scene; furthermore, cultural assimilation (or acculturation) of the minority group may take place even when none of the other types of assimilation occurs simultaneously,

and this condition of "acculturation only" may continue indefinitely.

In the case of the Japanese Americans, acculturation for the Issei was difficult. In order for full acculturation to be attained, cultural differences needed to disappear. This includes not only such aspects of the culture as clothing, manners, language, food and sports that are relatively easy to imitate, but also such less tangible elements as values, beliefs, ideas, memories and attitudes. However, some psycho-cultural problems the Issei faced were 
beyond their ability to conquer. This was particularly true in the acquisition of the English language. The retention of the use of ${ }^{\circ}$ the Japanese 1 anguage among the Issei has been thus very high.

The Issei have attempted to live in two worlds, Japanese and American. They have struggled to achieve reconciliation between the Japanese and American cultures. The same thing, but to a lesser extent, can be said concerning the Nisei, an identity problem.is involved in their case. Actually, the Issei were reasonably successful in insulating themselves within their ethnic group. The Nisei on the other hand were marginal.. Exposed to both the ethnic community and the dominant group, they were marginal to both. As for the Sansei, there is a concensus that they have attained a high degree of acculturation in terms of cultural, or behavioral assimilation. Regarding Sansei assimilation, Iga (Op. cit., 141) reported that "the only factor which prevents them from complete assimilation seems to be the combination of their physical visibility. and racial prejudice on the part of dominant group members." Based upon the arguments thus far, it is postulated that the different stages have been taking place in varying degrees. More specifically, it is postulated that.intergenerational differences are observable with respect to the extent of acculturation. 
Compatibility and Incompatibility of the Japanese Values with the American Value System

With respect to acculturation of the Japanese Americans, Caudil (1952) stressed the compatibility of traditional Japanese values and the American middle-class values. Shared values include: politeness, duty to the community, diligence, cleanliness and neatness, emphasis on personal achievement and long-range goals, a sense of guilt concerning nonsanctioned behavior, and the importance of keeping up one's appearance.

On the other hand, Kitano (1976) emphasized the "functional compatibility" and interaction between the two cultures rather than their cultural similarities. According to Kitano, the Issei have not acculturated but have retained most of the ways of the traditional Japanese culture. If the assumption that the Issei are both "tradition-directed" and "inner-directed" is correct, as Riesman (Op. cit.: 16) has asserted, they possessed a considerable degree of flexibility in adapting themselves to the circumstances.

Unquestionably, it can be stated that parts of traditional Japanese culture are still retained in the Japanese-American community. Examples include the retention of the Japanese language. Nearly all the Japanese immigrants retained their mother tongue. Also, the Kenjinkai and other ethnic organizations published newspapers or other organs for information. At the same time, 
however, some traditional Japanese values have been relinquished due to the adaptive mechanism of human behavior. According to Kitano (1976: 141), relinquished values include: authoritative discipline, blind obedience to ritual, extensive use of guilt and shame to shape behavior, and the submissiveness of females.

Thus, the transformational aspects of values need to be studied in order to understand the actual condition of acculturation and the degree of retention of the traditional culture in three generations of the Japanese Americans .

Some Notes Regarding Success Orientation of Japanese Americans

It can be stated here that the major assumption in this study is that each generation has its own distinctive characteristics in its degree of acculturation. Moreover, it is argued that a principal objective of the Japanese Americans has been toward being "successful."

The meaning of the term success should be clarified to avoid confusion. According to The American Heritage Dictionary of the English Language (1977), the term success has the following meanings:

1) The achievement of something desired or attempted.

2) The gaining of fame or prosperity.

3) One that succeeds.

The Random House Dictionary (1978) defines the term success as follows: 
1) A favorable result that one has tried or hoped for.

2) The attainment of wealth, fame, etc.

3) A successful person or thing.

Herein, when reference is made to the "success story," it means the achievement of something desired or attempted which has a favorable result, usually accompanied by socioeconomic attainment.

Williams $(1951,1960,1970)$ has classified "achievement and success" as one of the major value orientations in the United States. In his American Society: A Sociological Interpretation, Williams noted that American culture places a central stress upon personal achievement, especially secular occupational achievement. American society thus features a high degree of competitiveness in which ascribed status in the form of fixed, hereditary social stratification is minimized.

The success pattern is linked to achievement; this is endorsed by the belief that "success is seldom achieved without hard work." "Because of the preoccupation with business," asserted Williams (1951: 390), "the most conspicuous achievements have been those centered in business enterprise." Thus, the "economic success" is highlighted in most success stories. Specifically, in the success story a focal point is the level of pecuniary rewards a person attained throughout his life.

Discussing wealth as one salient aspect of the 
achievement patterns, Williams put it:

The central type of achievement is in business, manufacturing, commerce, finance; and since traditionalized social hierarchies, fixed estates, and established symbols of hereditary rank have had only a rudimentary development, there is a strong tendency to use money as a symbol of success. Money comes to be valued not only for itself and for the goods it will buy, but as symbolic evidence of success and, thereby, of personal worth (Williams 1951: 393).

Based upon the discussion above, the "success story" of the Japanese Americans in this study is concerned with, first, their occupational achievement in terms of occupational success; and second, their achievement in remuneration, or financial success. Furthermore, because it has commonly believed that Japanese Americans put high emphasis on formal education to attain their success, their educational achievement, or educational success would also be a matter of concern in this study.

The central argument of this thesis contends that many of the traditional Japanese values are consistent with the Protestant ethic. If Weber is correct, the Protestant ethic was instrumental in the development of Capitalism. It follows, then, that those who embrace the Protestant ethic will be more successful than those who do not. Therefore, it is hypothesized that if Japanese Americans have retained traditional Japanese values that are congruent with the Protestant ethic and/or relinquished incongruent ones, they would be successful. 
Study Hypotheses

A set of hypotheses regarding the retention-relinquishment pattern of the values and one's success is articulated. That is to say, among Japanese Americans:

1) Those who have retained traditional Japanese values which are congruent with dominant American value system are more likely to be successful than those who have not.

2) Those who have relinquished traditional Japanese values which are congruent with dominant American value system are less likely to be successful than those who have not.

3) Those who have retained traditional Japanese values which are incongruent with dominant American value system are less likely to be successful than those who have not.

4) Those who have relinquished traditional Japanese values which are incongruent with dominant American value system are more likely to be successful than those who have not.

However, in the case of Issei, there would be exceptions because they have insulated themselves from the dominant American society. In their case, therefore, the "success story" has been possible within the community of Japanese Americans. Accordingly, if Issei are excluded, the degree of acculturation would be a predictor of one's occupational and pecuniary success. With regard to educational success, it is assumed that the causation might be backwards, i. e., educational achievement could be a predictor of the degree of acculturation. Besides, it is hypothesized that one's educational success could be a predictor of one's occupational and pecuniary success. 
In the argument presented above, because the proposition 2 could be implied by the proposition 1 and the proposition 3 could be implied by the proposition 4 , these are to be integrated into the proposition 1 and 4 , respectively. Therefore, the clarified hypotheses are:

1) Those who have retained the traditional Japanese values which are congruent with dominant American value system are more likely to be successful than those who have not.

2) Those who have relinquished the traditional Japanese values which are incongruent with dominant American value system are more likely to be successful than those who have not.

In these study hypotheses, the independent variable is the degree of acculturation and the dependent variable is "sucçessfulness" which includes occupational and financial success.

With regard to educational success, the study will treat educational achievement as an "ambivalent" variable because educational achievement is assumed to be both cause and effect of the degree of acculturation. 


\section{REFERENCES FOR CHAPTER III}

Albert, Ethe1 M.

i956 "The Classification of Values: A Method and Illustration." American Anthropologist 58:

$221-48$.

Arkoff, Abe

1959

"Need Patterns in Two Generations of JapaneseAmericans in Hawaii." The Journal of Social Psychology 50: 75-9.

Gerald M. Meredith and Shinkuro Iwahara

"Dominance-Deference Patterning in Motherland Japanese, Japanese-American, and CaucasianAmerican Students." The Journal of Social Psychology 58: 61-6.

1964 "Male-Dominant and Equalitarian Attitudes in Japanese, Japanese-American, and CaucasianAmerican Students." The Journal of Social Psychology 64: 225-9.

Caudill, William

1952 "Japanese-American Personality and Accultura-

tion." Genetic Psychology Monographs 45: 3-102.

Davies, Peter, ed.

1977 The American Heritage Dictionary of the English Language. Paperback Edition. New York: Dell Publishing Co., Inc.

DeVos, George

1955 "A Quantitative Rorschach Assessment of Ma1adjustment and Rigidty in Acculturating Japanese Americans." Genetic Psychology Monographs 52: $51-87$.

Gordon, Milton M.

1964 Assimilation in American Life: The Role of Race, Religion, and National Origins. New York: Oxford University Press. 
Hraba, Joseph

1979 American Ethnicity. Itasca, Illinois: F. E. Peacock Publishers, Inc.

Iga, Mamoru

1966 "Changes in Value Orientations of JapaneseAmericans." Quoted in Harry H. L. Kitano, Japanese Americans: The Evolution of a Subculture (1976: Second Edition). New Jersey: Prentice-Hall.

Kitano, Harry H. L.

1976 Japanese Americans: The Evolution of a SubPrentice-Hali, Inc. Second Edition.

Kluckhohn, Clyde

1951 "Values and Value-Orientations in the Theory of Action." In Talcott Parsons and Edward A. Shils, eds., Toward a General Theory of Action. Massachusetts: Harvard University Press. $388-433$.

Kluckhohn, Florence R. and Fred L. Strodtbeck

1961 Variations in Value Orientations. Evanston, IIIinois: Row, Peterson and Company.

Light, Ivan $\mathrm{H}$.

1972 Ethnic Enterprise in America: Business and Welfare Among Chinese, Japanese and Blacks. Berkeley and Los Angeles, California: University of California Press.

Meredith, Gerald M. and Connie G. W. Meredith

1966 "Acculturation and Personality Among JapaneseAmerican College Students in Hawaii." The Journal of Social Psychology 68: $175-82$.

Merton, Robert $K$.

1968 Social Theory and Social Structure. New York: The Free Press. 1968 Enlarged Edition.

Parsons, Talcott

1970 "Youth in the Context of American Society."

[1962] In his Social Structure and Personality ([1964], 1970). New York: The Free Press. and Robert F. Bales

1955 Family, Socialization and Interaction Process. New York: The Free Press. 
and Edward A. Shils

1951 Toward a General Theory of Action. Cambridge, Massachusetts: Harvard University Press.

Petersen, William

1971 Japanese Americans: Oppression and Success. New York: Random House, Inc.

Reischauer, Edwin 0.

1969 Foreward to Bill Hosokawa. Nisei: The Quiet Americans. New York: William Morrow and Co., Inc., p. xi.

1977 The Japanese. Cambridge, Massachusetts: Harvard University Press.

Riesman, David with Nathan Glazer and Reue1 Denney

1961 The Lonely Crowd: A Study of the Changing American Character. New Haven, Connecticut: Yale University Press. Abridged Edition.

Stein, Jess and P. Y. Su, eds.,

1978 The Random House Dictionary. New York:

Ballantine Books.

Theodorson, George A. and Archilles G. Theodorson

1969 A Modern Dictionary of Sociology. New York:

Barnes and Noble Books.

Thomas, William I. and Florian Znaniecki

1918 The Polish Peasant in Europe and America. New

York: Dover Publications.

H. Paul Varley

1973 Japanese Culture: A Sort History. Tokyo:

Charles E. Tuttle Company.

Weber, Max

1958 The Protestant Ethic and the Spirit of Capitalism.

Translated by Talcott Parsons. New York:

Charles Scribner's Sons. Originally published in German in 1904-5.

Williams, Jr., Robin M.

1970 American Society: A Sociological Interpreta-

tion. New York: Alfred A. Knopf, Inc. Third Edition. (First Edition in 1951; Second Edition in 1960.) 
CHAPTER IV

PROCEDURES OF THE STUDY

The Samp1ing Method

According to the spokesman for the Japanese Consulate of Portland, Oregon, the total population of Japanese Americans in the city of Portland and its suburbs was estimated to be 2,950 on October 1, 1978. This figure is an extrapolation from the 1970 U. S. Census. This figure consists of four or five generations including three adult generations although the percentage in each generation is unknown. Moreover, there is no such thing as a directory of Japanese Americans for Portland.

Despite the fact that Japanese names can be easily identified, the telephone directory is not a completely reliable source for the identification of the Japanese American population. There are several defects of using the telephone directory. First, this method can not cover people whose names do not appear in the pages of the directory. Second, there are changes of the last name, from Japanese to non-Japanese, in the case of interracial marriage of Japanese women. Third, according to the Japanese Consulate, there are approximately 440 Japanese who are visiting Portland temporarily for various reasons. 
Such persons include dispatched officer workers from Japanese companies or banks, their families, students, diplomats, missionaries, and so forth. Further, there are some four hundred Japanese who do not yet possess American citizenship but are planning to settle in the United States. Therefore, more than eight hundred persons, who are not Japanese Americans, could not be distinguished from the Japanese-American population of 2,950 were the telephone directory used.

Another alternative for the selection of the sample was to use the directories of such organizations as the Japanese Ancestral Society (JAS), the Japanese Ancestral Women's Club (JAWC), and the Japanese American Citizens' League (JACL). Fortunately, the directories of those ethnic organizations were made available for this study through the writer's acquaintances. The uses of the directories was permitted by each organization for the pursuit of this study. ${ }^{1}$ Char : acteristics of those directories are described below.

The directory of the Japanese Ancestral Society (or Nikkeijinkai) for the year of 1979 consisted of 344 members which included both Issei and Nisei. The Nisei members were mostly those who were born in the United States and sent to Japan for a substantial portion of their formative years; they received most of their education in Japan.

$1_{\text {This }}$ research project was also approved by the Human Subjects Research Review Committee of Portland State University. 
They are called Kibei-nisei or simply Kibei. The writer was told by one Kibei woman that she would feel much more comfortable being with Issei rather than with "pure" Nisei because Kibei are much less Americanized than "pure" Nisei. As evidence, most Kibei still use the Japanese language in their everyday life, and many Kibei women have married Issei men. The JAS directory has been revised every year to reflect death or change of the addresses of members. The numbers of the Issei members have been decreasing proportionate to the numbers of the Nisei members including the Kibei.

The directory of the Japanese Ancestral Women's Club (or Nikkei-fujin-kai) for the year of 1979 lists 124 members. Among them, by December 31, 1979, 6 had died, 1 had moved, 6 were Nisei, 17 were kibei, 8 were the socalled "war brides," 2 and 34 members overlapped with the JAS roster. Therefore, it contained 92 useful names of female Issei members.

With respect to the directory of the Japanese American Citizens' League, the newest directory was one edited in 1967 which contained 320 names and addresses of Nisei members and 68 names and addresses of Sansei members. Because the directory was twelve years old, all the names and

${ }^{2}$ War brides are those who came to the United States as wives of American soldiers after the American occupation of Japan (1945-52). The number of the emigrated war brides is estimated to be at least 40,000 . Their age structure is almost identical with that of the Nisei. 
addresses were checked in the telephone directory. As a result, $209 \mathrm{Nisei}$ and 42 Sansei were identified in the telephone directory.

Because the 1967 JACL directory did not contain enough names and addresses of Sansei members, names and present addresses of the Sansei were collected from as many sources as available. A name and address list for the Sansei was edited by the writer with the cooperation of the writer's Sansei friends. Above all, the membership rolls of the Japanese American Bowling C1ub were examined because the club consisted of a fairly large number of the Sansei. Fifty names and addresses of the Sansei members were collected from this source. All duplicate names were eliminated from this list. All of these efforts resulted in the compilation of 162 names and addresses of the Sansei.

A sample was selected, consisting of three hundred persons, one hundred from each of the three generations.

The Issei Sample

Owing to the effort by Mr. George Azumano, the former president of the Japanese Ancestral Society, 43 names of male Issei were extracted from the 1979 JAS directory. Those selected were the Issei who were over sixty years of age and those who immigrated to the United States before the Second World War. From the 1979 JAWC directory which contained 92 names of female Issei, 57 names were randomly selected. The table of random numbers in Babbie's Survey 
Research Method (1973: 373-6) was used. Accordingly, the Issei sample ultimately consisted of 43 males and 57 females.

The Nisei Sample

As was mentioned before, the 1967 JACL directory contained 209 identifiable names and addresses of Nisei members. Among them were 153 males and 56 females. In addition to those, 62 names of male Nisei were extracted from the 1979 JAS Membership roster. Five names of female Nisei and 17 names of female Kibei were found in the 1979 JAWC membership roster. All duplicate names were eliminated. The effort resulted in the compilation of 265 names of the Nisei; 187 of which were male and 78 of which were female. Those names were numbered from 001 to 265; and 100 names were randomly selected using the tables of random numbers in Babbie's Survey Research Method. The sample consisted of 71 males and 29 females.

The Sansei Sample

The sampling method was a little different for the Sansei from that employed in the cases of Issei and Nisei. This difference in method was made necessary primarily because the 1967 JACL directory did not contain enough names and addresses of the Sansei. Therefore, names and addresses from other sources were needed. 3

$3^{3}$ The writer's Sansei acquaintances such as Miss 
Eventually, 120 names and addresses of the Sansei were collected. The 120 names included 50 of the Sansei membership of the Japanese American Bowling Club of Portland. The total listing of Sansei contained 162 names. From those, 100 were randomly selected by the same method used in the cases of the Issei and Nisei sample. The sample consisted of 56 males and 44 females.

An Overview of the Sample

The total number of the Japanese-American population that was found is described in Table II. The total names that were identified were thus, 562. This figure is approximately $20 \%$ of the total Japanese-American population of 2,950 who live in the city of Portland and its suburbs. The total sample size of 300 is approximately $10 \%$ of the population of the Japanese Americans of the Portland area. This area was delimited to Portland, Beaverton, Boring, Gresham, Hillsboro, Lake Oswego, Milwaukie, Oregon City, Sherwood, Tigard and Tualatin. The Washington side of the Columbia River including Vancouver was excluded.

Christy Iwasaki and Miss Teri Imai were very cooperative in this endeavor. Names were provided also by $\mathrm{Mr}$. Sho Dozono, President of the Japanese American Citizen's League. My thanks for their cooperation. 
TABLE I I

THE JAPANESE-AMERICAN POPULATION UTILIZED IN THE STUDY

\begin{tabular}{rrr} 
Male & Female & Total \\
\cline { 2 - 3 } 43 & 92 & 135 \\
187 & 78 & 265 \\
89 & 73 & 162 \\
\hline 319 & 243 & 562
\end{tabular}

Data Collection

The study data were obtained by the use of selfmailing questionnaire, accompanied by a letter of explanation and a return envelope. The purpose of the study was described in the introductory letter. The research office's return address (- i. e., Department of Sociology, Portland State Univeristy --) was pre-typed on a stamped envelope. First class mail postage was used.

The questionnaire and the introductory letter 4 sent to members of the Issei samples were translated by the writer into Japanese because it was assumed that the return rate would be higher were the questionnaire written in Japanese instead of in English. 5

A follow-up mailing was sent to all the persons in the samples one week after the questionnaires were mailed. Postcards were used for this mailing. The follow-ups sent to the Issei respondents were also translated into Japanese. 6

4,5,6Samples are seen in Appendix. 
The details of the response characteristics are shown in Table III.

\author{
TABLE I I I
}

THE RESPONSE CHARACTERISTICS

\begin{tabular}{rrrr} 
Day & $\begin{array}{c}\text { Number of } \\
\text { Responses }\end{array}$ & Total & $\%$ (cumulative) \\
\hline 4 & 2 & 2 & 0.7 \\
5 & 22 & 24 & 8.0 \\
6 & 4 & 28 & 9.3 \\
7 & 32 & 60 & 20.0 \\
11 & 11 & 71 & 23.7 \\
12 & 22 & 93 & 31.0 \\
13 & 7 & 100 & 33.3 \\
14 & 2 & 102 & 35.7 \\
18 & 5 & 107 & 37.0 \\
20 & 4 & 111 & 37.3 \\
21 & 1 & 112 & 37.7 \\
25 & 1 & 113 & 38.0 \\
32 & 1 & 114 &
\end{tabular}

Within one week after the first mailing, the response was $20 \%$; within two weeks after the follow-up mailing, an additional $17 \%$ of the questionnaires were returned. The characteristics of the respondents by generation and gender are shown in Table IV. 


\section{TABLE IV}

RESPONDENT RATIO BY GENERATION AND GENDER

\begin{tabular}{|c|c|c|c|}
\hline Generation & Male & Female & Tota $1(\%)$ \\
\hline Issei & 15 & 19 & $32(28.0)$ \\
\hline Nisei & 27 & 13 & $40(35.1)$ \\
\hline Sansei & 17 & 16 & $33(29.0)$ \\
\hline Others* & 5 & 4 & $9(7.9)$ \\
\hline Total & 64 & 50 & $114(100.0)$ \\
\hline
\end{tabular}

* "Others" are the so-called "in-betweens." Examples of such "in-betweens" include: Father - Issei, Mother Nisei; or Father - Caucasian American, Mother - Issei.

According to Table IV, the responses from Nisei are approximately $10 \%$ higher than the responses from either Issei or Sansei. Because the writer's home telephone number appeared on the questionnaire, the writer received several telephone calls from the respondents who were particularly interested in the study. Those who called the writer were, interestingly enough, all Nisei.

Several Issei respondents enclosed letters with the completed questionnaires; three of them urged the writer to telephone them so that they could provide additional information on the phone. Conversations with them (two males and one female) were very informative and their cooperation was highly appreciated.

Measures Utilized in the Study

To the extent that research and theory ought to be 
related to one another, care needs to be given to the ways in which abstract concepts and their definitions are related to variables and their operationalization. In the hypotheses formulated in the previous chapter, there are concepts which need to be operationalized; those concepts are, the degree of acculturation and the degrees of occupational, financial and educational success.

\section{1) Degree of Acculturation. Acculturation was} defined in this study to be a "synonym of cultural (or behavioral) assimilation". In other words, acculturation is a modification of a certain culture pattern which occurs through contact with other cultures. This means that acculturation is a process of the fusion of a particular ethnic pattern with a different culture. Different racial and ethnic groups acculturate by becoming similar in their thinking, feeling and acting with the patterns in the dominant culture (Hraba, 1979: 29).

In this study, the degree of acculturation is measured by two different methods. One method is self-judged identity and the other is the use of a set of value questions which was developed by the writer. Self-judged ethnic identity was measured by a scale of one-to-ten, a value of one representing a complete American identity and a value of ten representing a complete Japanese identity. The actual question asked was:

Let us assume that on a scale of one-to-ten, a complete 
Japanese identity be given a value of 10 and a complete American identity a value of 1 . Indicate the number which in your judgment most closely describes your ethnic identity.

The value questions were designed to measure the extent of value-internalization of the subjects. Some 34 values were represented. ${ }^{7}$ The respondents were asked to check one of five categories. Those categories are: 1) Very Important, 2) Important, 3) Somewhat Important, 4) Somewhat Unimportant, and 5) Unimportant. An instruction was given at the beginning of this section which was entitled "Question About Your Opinions." The instruction given was:

In this section, questions about your opinions to thirty-four words or phrases will be asked. Those words or phrases are considered to be "values" or "standards of behavior." Please check the category that best applies to you.

An example of the value questions is as follows:

Repayment of kindness which one received in the past

Very Important
Important
Somewhat Important
Somewhat Unimportant
Unimportant

The 34 values were the mixture of traditional Japanese values and American middle-class values. Those values were extracted from classic literature which have dealt with either American or Japanese culture. Among those sources include The Chrysanthemum and the Sword: Patterns of

${ }^{7} \mathrm{~A}$ list of the selected values is seen in Appendix A. 
Japanese Culture (Benedict, 1946), American Society:

A Sociological Interpretation (Williams, 1951),

Delinquent Boys: The Culture of the Gang (Cohen, 1955).

The selected values were arranged randomly in the questionnaire.

2) Degree of Occupational Success. With respect to the variable of "the degree of occupational success," Duncan's Socio-Economic Index Scores 8 were used to classify respondents' occupations. Duncan's occupational scale takes values between 0 and 100 to indicate prestige ranking of each occupational category. For example, the score of 93 is given to lawyer and judges, one of the highest occupational categories, and the score of 0 is assigned to laborers in the tobacco manufacturing, the lowest score among the categories.

Reliability problems were anticipated regarding the use of Duncan's Socio-Economic Index Scores when respondent's description of his/her occupation was to be translated into a numerical number. In order to minimize this problem, the question was asked in the following manner:

What kind of occupation are you currently engaged in? (Be specific please. For example, teacher of English in a high school, or supervisor of electronics quality control.

${ }^{8}$ Otis D. Duncan, in Albert J. Reise, Jr., Occupations and Social Status (1961), pp. 263-75. 
3) Degree of Financial Success. This variable was measured by simply providing a question concerning the respondent's family income. The question asked was:

What is currently the average total annual income before taxes of your family? Please check the most appropriate category.

Twenty ordinal categories were provided after the above question. Below $\$ 20,000$, the response categories were in class intervals of $\$ 2,500$. From $\$ 20,000$ to $\$ 74,999$, the intervals were increased to $\$ 5,000$. The lowest category was "Less than $\$ 2,500 "$ and the highest category was "\$75,000 and over.".

4) Degree of Educational Success. The last variable in the set of hypotheses of this study is "the degree of educational success." Data on the completed education of the respondents and their parents were obtained by asking the following question:

How much formal education have you and your parents completed? Please check all that apply.

Twelve categories were provided after the above question. Those are:

1) No formal education

2) Some elementary school

3) Completed elementary school

4) Some junior high school

5) Completed junior high school

6) Some high school

7) Completed high school

8) Some college

9) Completed college

10) Post graduate work, but no advanced degrees

11) One or more graduate degrees

12) I am not at all sure 
To determine the kind of colleges, professional school, regular liberal arts college, or trade school, the following question accompanied the above question:

If you or your parents had some college or more education, what kind of college was that? (For example: regular liberal arts college, dental college, business college, beauty college, etc.)

In the couple of questions mentioned above, spaces were provided for the following categories: 1) Yourself, 2) Father, 3) Mother, 4) Stepfather, and 5) Stepmother.

\section{Data Processing}

The data obtained by the completed questionnaires were coded into numbers for computer processing. Codes were developed in the manner as described in the Appendix. After the data were coded, the set of numbers was transferred onto a deck of cards using the IBM Mode1 26 keypunch machine. Programs for the analysis were selected from the Statistical Package for the Social Sciences (S.P.S.S.) system. ${ }^{9}$ The set of data was processed by the Honeywe11 66/20 computer system at Portland State University.

${ }^{9}$ Programs were available in the following material. Norman H. Nie, et a1., Statistical Package for the Social Sciences $(1975)$. 
Babbie, Earl R.

1973 Survey Research Methods. Belmont, California: Wadsworth Publishing Company, Inc.

Benedict, Ruth

1946 The Chrysanthemum and the Sword: Patterns of Japanese Culture. New York, New American Library.

Cohen, Albert $K$.

1955 Delinquent Boys: The Culture of the Gang. Glencoe, Illinois: The Free Press.

Hraba, Joseph

1979 American Ethnicity. Itasca, Illinois: F. E. Peacock Publishers, Inc.

Nie, Norman H., et al.

1975 Statistical Package for the Social Sciences. New York: McGraw-Hil1 Book Company

Reiss, Jr., Albert J.

1961 Occupations and Social Status. New York: The Free Press.

Williams, Jr., Robin M.

1951 American Society: A Sociological Interpretation. New York: Alfred A. Knopf, Ine. 


\section{CHAPTER V}

\section{FINDINGS}

Introduction

In this chapter, the results of the data analysis will be described. Because "successfulness" of the Japanese Americans is in this study concerned with three aspects, each aspect will be treated independently in relation to the degree of acculturation. With regard to "acculturation," because this study employed dual operationalization to measure the degree of acculturation, each will be treated separately.

Marginal Distribution

Table $V$ shows the marginal distribution of the major variables by generation. According to this table, there are significant differences in the mean scores of each variable. As far as the levels of occupational and financial success are concerned, the Nisei sample showed the highest scores. As for the level of educational success, the Sansei sample showed the highest score. With regard to the degree of value embracement and self-judged ethnic identity, this table shows that there is a trend in the three generations. That is, the older the generation, the greater the probability that an individual puts emphasis 
on both Japanese values and American values. Also, the Issei tend to identify themselves as Japanese and the Sansei tend to identify themselves as American, the Nisei are in between the Issei and Sansei.

TABLE V

MARGINAL DISTRIBUTION BY GENERATION

\begin{tabular}{|c|c|c|c|c|c|c|c|}
\hline \multirow[b]{2}{*}{ 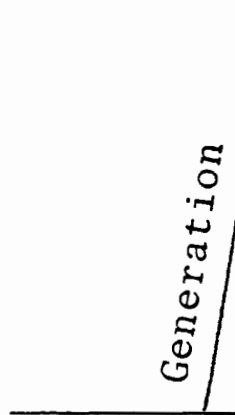 } & \multicolumn{7}{|c|}{ Mean Scores } \\
\hline & 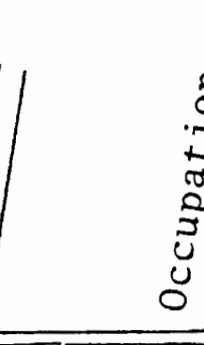 & $\underset{\Xi}{\stackrel{\Xi}{\Xi}}$ & ĩ & 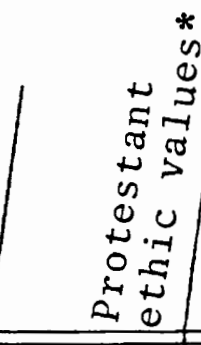 & 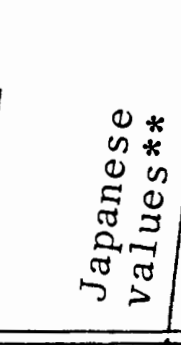 & 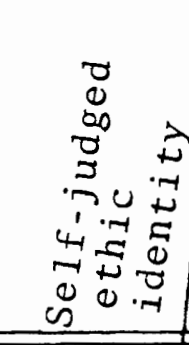 & 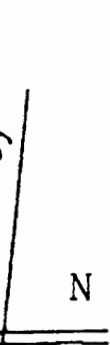 \\
\hline Issei & 41.375 & 4.800 & 5.292 & 3.250 & 3.285 & 6.529 & 32 \\
\hline Nisei & 61.639 & 12.838 & 8.575 & 3.194 & 2.583 & 5.892 & 40 \\
\hline Sanse $i$ & 56.107 & 7.500 & 9.152 & 2.898 & 2.156 & 4.625 & 33 \\
\hline Total & 57.236 & 9.188 & 7.959 & 3.099 & 2.628 & 5.688 & 105 \\
\hline
\end{tabular}

*"Protestant ethic values" are referred here to represent traditional Japanese values which are congruent with American value system.

**"Japanese values" are referred here to represent traditional Japanese values which are incongruent with American value system.

Now, let us start analyzing the findings.

Verification of the First Hypothesis

As stated in Chapter III, the first hypothesis of this study is: 
Those who have retained traditional Japanese values which are congruent with dominant American value system are more likely to be successful than those who have not.

This hypothesis suggested that Japanese Americans who embrace values compatible with those generally called the "Protestant ethic" will show more success in American society. Here success is defined in three ways; namely, the level of occupational ranking, income and educational achievement. Furthermore, we expect that the ratio between values and success will be mitigated by generation in that not only do the values vary by generation but also the effect of values on success will also vary.

With regard to "traditional Japanese values which are congruent with the dominant American value system," it appears that these values are very similar to the socalled Protestant ethic. ${ }^{1}$ Among these values include: credit to one's own name, educational achievement, work as virtue, success, courteousness, self-discipline, selfcontrol, and asceticism (including "industry" and "thrift"). From now on, these values would be called "Protestant ethic values."

Table VI shows the statistical associations between the degree of embracement of "Protestant ethic values" and

$1_{\text {Max }}$ Weber speculated that human behavior might be affected to some extent by religious thought. He hypothesized that the spirit of capitalism was likely to be the effect of the Protestant ethic. In this argument, he emphasized the ascetic aspect of the protestant ethic. In this thesis, however, the Protestant ethic is interpreted more loosely to be related to Western individualism. 
the level of occupational, financial and educational

achievement by generation. Gamma was utilized to measure the associations between the independent and dependent variables.

\section{TABLE VI}

THE DEGREE OF EMBRACEMENT OF PROTESTANT ETHIC VALUES BY OCCUPATION, INCOME AND EDUCATION BY GENERATION (FIGURE = GAMMA)

Generation

Issei

Nisei

Sanse $i$

\section{Occupation}

0.231

0.293

$-0.069$

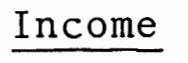

$-0.287$

0.188

0.087
$\underline{\mathrm{N}}$

32

40

Total

0.096

0.030

$-0.063$

105

First of all, let us take a look at the total category. For the whole population, there are very weak associations between embracement of protestant ethic values and the three measures of success. Only the notable relationship in the total category would be the difference of the sign. ${ }^{2}$ However, when the data are differentiated by generation, it revealed some associations between the degree

${ }^{2}$ A positive sign of gamma indicates that the dependent variable varies in accordance with the direction of variance of the independent variables, whereas a negative sign indicates that the dependent variable varies in the opposite way of the independent variable. 
of embracement of Protestant ethic values and success patterns.

In relation to occupational achievement, moderately strong positive correlations were found among the Issei and Nisei samples. In the case of the Sansei, the relationship is reverse even though the intensity of correlation is weak. The values of gamma in Table VI represent the percentages of possible reduction of errors in predicting occupational success by the knowledge of the degree of embracement of Protestant ethic values. In the cases of the Issei and Nisei samples, $23.1 \%$ and $25.3 \%$ of errors can be reduced in predicting one's occupational success if the information regarding the degree of embracement of the Protestant ethic values is available.

Consequently, one could conclude that, as far as occupational successfulness of the Issei and Nisei is concerned, the first hypothesis is supported.

It was revealed, however, that this hypothesis would not have validity for the Sansei sample. According to Table VI, the relationship between the degree of embracement of Protestant ethic values and occupational success among the Sansei respondents was reverse of the cases of Issei and Nisei. That is to say, among the Sansei, the lower the degree of embracement of Protestant ethic values, the greater the probability that an individual would achieve a higher level of occupational success. In other words, embracement of Protestant ethic values functioned as an 
impediment for them to obtain a higher occupation. What $k$ ind of reason was there which made it possible for the Sansei to nurture this situation?

In the Sansei sample, there was a negative correlation between educational achievement and the probability for an individual to embrace Protestant ethic values. Therefore, one could argue that: 1) higher education influences the Sansei in rejecting the Protestant ethic values; and 2) the higher his/her educational background, the greater the probability that a Sansei would possess a higher level of eccupation; hence 3) the higher the educational achievement, the lower the degree of embracement of the Protestant ethic values, therefore, the greater the probability that a Sansei would achieve a higher level of occupational success. Thus, it is inferred that, among the Sansei, educational achievement is the key to occupational success. In other words, embracement of Protestant ethic values should be considered merely as a partial cause of their occupational achievement. 3

Next, with regard to the relationship between Protestant ethic values and financial achievement, two

${ }^{3}$ Presumably, the direct cause of occupational success for the Sansei might be their educational achievement. The value of gamma between educational achievement and occupational success was 0.523 ; this value is high enough to conclude that education is a primary cause of the Sansei's occupational success. That is to say, this value represents that $52.3 \%$ of errors can be reduced in predicting one's occupational success were his/her educational background known. 
propositions are articulated as follows:

Among the Issei, the lower the degree of embracement of Protestant ethic values, the greater the probability that an individual would be financially successful. (Proposition 1)

Among the Nisei, the higher the degree of embracement of Protestant ethic values, the greater the probability that an individual would be financially successful. (Proposition 2)

It was found that proposition number one rejects the acculturation-success hypothesis. Among the Issei respondents, those who have not embraced traditional Japanese values which are congruent with the dominant American value system were more likely to be successful than those who have. This would suggest that embracement of the American values (i.e., Protestant ethic values) functioned as a hindrance to financial success for the Issei.

On the other hand, the first study hypothesis is supported by the Nisei respondents. Proposition number two represents the positive causal relationship between the degree of embracement of Protestant ethic values and financial success. Consequently, it might lead us to a conclusion that Weber's hypothesis about the Protestant ethic and the spirit of capitalism would be relevant to the case of the Nisei.

Lastly, with regard to verification of the first hypothesis, our argument proceeds to the third variable; namely, educational achievement. As mentioned before, in the educational category, the causal direction may run 
either way. That is to say, education may cause one to internalize Protestant ethic values as well as the internalized Protestant ethic values causing one to achieve higher education. What kind of relationships are there between educational achievement and the formation of personal value system in the three generations?

The Nisei's case should be noted in comparison with the cases of Issei and Sansei, namely, the Nisei shows the strongest intensity as well as the opposite sign of gamma. A set of proposition is articulated as follows:

Among the Nisei, the higher the degree of embracement of Protestant ethic values, the greater the probability that an individual would achieve a higher level of educational achievement. (Proposition 3)

Among the Nisei, the higher the educational achievement, the greater the probability that an individual would embrace protestant ethic values. (Proposition 4)

According to the value of gamma in this correlation, $11.9 \%$ of errors could be reduced in predicting the educational achievement of the Nisei were the information about the degree of embracement of Protestant ethic values available, and vice versa.

Conversely, the sign of gamma is negative in the cases of Issei and Sansei. That is, it is less likely for both the Issei and Sansei to have achieved higher education if he/she has embraced a high degree of Protestant ethic values, or vice versa. This could be restated in the following propositions: 
Among the Issei and Sansei, the lower the degree of embracement of Protestant ethic values, the greater the probability that an individual would achieve a higher level of educational achievement. (Proposition 5)

Among the Issei and Sansei, the higher the educational achievement, the lower the probability that an individual would embrace Protestant ethic values. (Proposition 6)

Although the values of gamma are small, these propositions would have a significant meaning by contrast with the Nisei's case. Namely, in the case of Nisei, the acceptance of at least a part of the Protestant ethic is related to educational achievement; on the other hand, for the Issei and Sansei, educational achievement appears to have discouraged a person from embracing Protestant ethic values. Why is there a difference between the Nisei and the Issei/Sansei?

In order to explicate this intergenerational difference, one would have to consider the historical background of these three generations.

First of all, the "unique" age distribution in the community of the Japanese Americans should be noted. There is a serious gap in the age distribution among them. Moreover, distinctions are found between the three generational cohorts. ${ }^{4}$ The distinction is clear especially between the Issei cohort and the Nisei cohort. This phenomenon was

${ }^{4}$ A cohort is a group defined by calendar year of birth. It appears that each cohort has a so-called cohort effect. Statistically speaking, there seem to be a common feature among those who belong to a particular cohort by merely being a member of that cohort. 
presumably generated from a series of restrictions of Japanese immigration in years such as 1908, 1920 and 1924.

The Gentlemen's Agreement of 1908 between the American and Japanese government restricted the right of $1 \mathrm{a}-$ borers to emigrate from Japan to the United States. 5 Even so, other emigrants like "picture brides" were still allowed as long as labor was not the primary purpose of emigration. However, in 1920, due to the political pressure by the United States, the Japanese government was obliged to cease issuing passports to picture brides. Also, in the same year, the Alien Land Law was enacted which increased legitimate discrimination against non-white immigrants including the Japanese. In 1924, another discriminatory bill was enacted. The major purpose of this "1924 Immigrant Act" was to exclude the Japanese from the United States. The Japanese immigration was thus totally prohibited by the enactment of this bill which remained effective until 1952 .

Consequently, the Japanese community in the United States was isolated. This isolation became a primary cause of the bias in its age structure. By the time the second generation reached adolescence, there were no middle-aged

${ }^{5}$ The purpose of this agreement between the two countries was to reduce the Japanese immigration to the United States through a voluntary effort. As a result, the Japanese government discouraged many potential Japanese laborers who wished to emigrate to the United States. 
people. A clear-cut distinction of the age stratification between the Issei and Nisei occurred. In addition, the two generations lacked verbal communication due to the Issei's inability to speak English. Some Nisei were able to speak Japanese. They were the Kibei ${ }^{6}$ who appeared to have functioned as "mediators" between the Issei and Nisei. However, despite the efforts by the Kibei, there was a serious generational gap. The Issei have been "alien" to their children, the Nisei, for the Issei still embraced Japanese identity despite their having lived in the United States more than half of their lives.

Even though there were the language problem and enormous age discrepancy between the Issei and Nisei, 7 the Issei expected their children to be successful in American society. In other words, the Issei wished their dream of success (the dream which they have been holding ever since they left their home country; namely, to return to Japan with a fortune) to be incarnated by the Nisei. To the Issei, education for the Nisei was one of the most effective ways to embody their wish. With regard to this, Kitagawa (1967: 37) has written:

No parents were satisfied to see his child go no

$6_{\text {With }}$ regard to the Kibei, see page 60 and 61 in Chapter IV.

${ }^{7}$ By and large, an enormous discrepancy in age structure between the Issei and Nisei is a common phenomenon in the Japanese-American community due to late marriages and the picture bride system. For example, the writer has a Nisei friend whose father is 52 years older than he. 
further than high school. The Issei sacrificed much in order to send his sons and daughters to college or at least vocational schools of posthigh school standard. College education was so common place among the Japanese Americans in the late 1930 's that those who did not go to college had quite severe reasons for it.

The present research shows $65.2 \%$ of the Nisei respondents had achieved an educational level beyond high school. On the other hand, among the same respondents, $8.1 \%$ of their fathers and $2.6 \%$ of their mothers had education beyond high school. From these figures, it might be inferred that the Nisei through interactions with their Issei parents internalized the values of higher education as we 11 as incentive to "get ahead."

Thus far, the arguments have been concerned with the Issei and Nisei. But what of the Sansei?

There is a weak negative correlation between their educational achievement and the probability of embracement of Protestant ethic values. How can it be explained sociologically?

As mentioned before, Protestant ethic values are represented in the present study by: 1) credit to one's own name, 2) educational achievement, 3) work as a virtue, 4) success, 5) self-discipline, 6) self-control, and 8) asceticism which includes "industry" and "thrift." The value of gamma $(-0.133)$ would suggest that among the Sansei sample, the degree of embracement of these values is negatively correlated to the educational achievement. That 
is, a Sansei whose educational background is relatively low might have more probability to embrace these values than those who have achieved higher education. A young Sansei might consider these values as "out-of-date" or "old-fashioned." 8 Presumably, it could be college education which discouraged the Sansei from embracing the "out-of-date" Protestant ethic values which he/she had internalized through interactions with his/her parents.

The positive correlation among the Nisei respondents between educational achievement and Protestant ethic values might be explained from the standpoint of their achievement orientation. Namely, one might hypothesize that because they were eager to identify themselves and to be identified by others to be "one hundred percent Americans," they tried to accept the American way of thinking, particularly the Protestant ethic which pervaded middle-class America. It appears that the Nisei did not try to make compromises with their parents' way of thinking.

${ }^{8}$ Incidentally, among the values which the Sansei respondents thought were important include: appreciation of human feelings, good personal relation, freedom, responsibility for one's conduct, and rationality. On the other hand, among the values which they thought were not important include: respect for the Emperor (of Japan), worship of ancestors, proper behavior in accordance with one's status, obedience, and willingness to sacrifice today for the gain in the future. Thus, the value system among the Sansei might be inferred as a new type which doesn't belong to either American middle-class value system or traditional Japanese value system. Incidentally, traditional Japanese values were strongly retained among the Issei and the Protestant ethic values were pervaded among the Nisei. For the details see Appendix L. 
Rather, they seem to have made a great effort to establish their American identity by denying those Japanese values which were alien to the dominant American values.

However, the "Nisei dilemma" would not disappear totally because some of the traditional Japanese values had already been internalized during their childhood. In addition, they could not totally eliminate their Japanese identity because of their appearances, names and kin relations. Thus, it would appear that the Nisei have always lived in the world of ambivalence. For this reason, the title "the quiet Americans" fits them perfectly as a description of the Nisei's ambivalent character.

We are now ready to proceed to our discussion of the next stage; namely, testing of the second hypothesis.

Verification of the Second Hypothesis

The second hypothesis of this study is:

Those who have relinquished traditional Japanese values which are incongruent with dominant American value system are more likely to be successful than those who have not.

This hypothesis suggested that Japanese Americans who relinquish values incompatible with the Protestant ethic will show more success in American society. With regard to "traditional Japanese values which are incongruent with the dominant American value system,"

${ }^{9}$ This title was given by Bill Hosokawa in his book entitled Nisei: The Quiet Americans (1969). 
the term "Japanese values" will be used from now on. Among these values include: filial duty, respect for one's superior, worship of ancestors, feeling of togetherness with one's clan, respect for the Emperor of Japan, and obedience.

Table VII shows the statistical associations between the degree of embracement of "Japanese values" and the level of occupational, financial and educational achievement by generation. To begin with, let us observe the total category. The values of gamma are relatively great particularly in the categories of educational and financial achievement. Furthermore, the sign of gamma are all negative. That is, occupational, financial and educational achievement are all in inverse proportion to the degree of embracement of Japanese values.

TABLE VII

THE DEGREE OF EMBRACEMENT OF JAPANESE VALUES BY OCCUPATION, INCOME AND EDUCATION BY GENERATION ( $F$ I GURE $=$ GAPMA $)$

\begin{tabular}{|c|c|c|c|c|}
\hline Generation & Occupation & Income & Education & $\underline{N}$ \\
\hline Issei & -0.400 & -0.554 & -0.383 & 32 \\
\hline Nisei & -0.062 & -0.128 & -0.293 & 40 \\
\hline Sanse $i$ & -0.176 & -0.233 & -0.476 & 33 \\
\hline Total & -0.094 & -0.268 & -0.447 & 105 \\
\hline
\end{tabular}


Subsequently, let us take a look at the figures by generation. With regard to occupational success, the Issei's case stands out. Forty percent of errors can be reduced in predicting one's occupational success by knowing the degree of relinquishment (or embracement) of traditional Japanese values which are incongruent with the dominant American value system. Consequently, it would lead us to a conclusion that there is a fairly strong causal relationship between the degree of relinquishment/ embracement of Japanese values and the level of occupational achievement in the case of Issei.

Moreover, if it is recalled, there was a positive relationship between the degree of embracement of Protestant ethic values and occupational success (Table VI). With respect to this correlation, a further discussion would be needed. Although occupational achievement should reflect both financial and educational achievement, occupational achievement in the Issei's case is positively related to the degree of embracement of Protestant ethic values whereas financial and educational achievement are negatively related. Because an occupational ranking is determined in Duncan's SEI scores by a value from a regression equation based upon income and education, financial and educational achievement should predict occupational achievement. Therefore, one would generally expect that for the Issei if financial and educational achievement were 
negatively related to the degree of embracement of Protestant ethic values, so should be occupational achievement.

However, the outcome of the present research betrayed this expectation. This might be explained as follows .

A study shows that a large population of the Japanese immigrants in California was working in small shops and businesses (Kitano, 1976: 21). These kinds of occupations were the second largest among them next to agriculture. This was also true among the Issei of the Portland area. Above a11, many of them have been working as craftsmen, service workers and operatives, that is, so-called "blue-collar workers." Examples of these occupations include: assemblers, barbers, cooks, cosmetologists, deliverymen, gardeners, laundry and dry cleaning operatives, different kinds of manufacturing workers, and non-manufacturing industry workers including railroad service workers, construction workers, wholesale and retail trade workers, and so forth. 10

Being involved in or being a part of the existence of the "guild" system is a common feature among these occupations. There are many Japanese guilds corresponding

${ }^{10}$ According to Duncan's classification of occupational categories, the mean scores of major occupational categories are: 31 for "craftsmen, foremen and kindred workers," 21 for "service workers (except private household)," and 18 for "operatives and kindred workers including mine labors." 
to each occupational category. As Light (1972: 68) has pointed out, the memberships in the guild (or trade association) tend to overlap with memberships in the Kenjinkai. With regard to this point, he writes:

Like the Kenjinkai, the trade guilds combined benevolent, social, economic and welfare functions. In this combination, the trade guilds went considerably beyond the normal range of activities of a Western trade association (Light, 1972: 68).

It appears that the Japanese guild system has nurtured strong solidarity among the members. Development of solidarity was necessary not only for benevolent reasons but also because of continuous anti-Japanese movements included acts from boycotts of Japanese businesses to terrorism against Japanese businessmen. Consequently, in order to protect themselves and survive in business, the Japanese merchants strengthened their unity through guild memberships.

Thus, the members of Japanese guild associations appear to have embraced conservative Japanese values which are incongruent with the American value system. On the other hand, those who were not members of those guild associations (who were presumably not members of Kenjinkai either) had emphasized the values of self-reliance, individualism, etc. and rejected the traditional values in order to more effectively compete in the larger community.

Besides, one could imagine that it is farily competitive to obtain a "good" occupation in a relatively small 
ethnic community. There would have been a limitation to allocate "good" occupations to the members of the community. Therefore, it could be argued that those who have relinquished Japanese values and/or embraced Protestant ethic values might have had better chances to obtain "good" occupations outside the community of Japanese Americans. In other words, those who have remained within the Japanese-American community might have had less chances to obtain "good" occupations.

Thus, for the Issei, the first and second study hypothesis are both supported as far as occupational success is concerned.

Now, the argument proceeds to financial achievement in relation to the degree of relinquishment/embracement of Japanese values.

The value of gamma in Table VII for the total category shows a fairly strong figure. Moreover, the sign is negative. This would suggest that embracement of Japanese values would discourage one's financial success. This tendency is characteristic throughout the three generations. In particular, the case of Issei is salient - $55.4 \%$ of errors can be reduced in predicting one's financial success by knowing whether or not an individual puts importance on the values which are incongruent with the dominant American value system. Gamma also shows a relatively high value in the case of Sansei. As for the Nisei, the relationship is 
positive but fairly weak compared to the Issei and Sansei. Consequently, one could speculate that Japanese values have a negative correlation with pecuniary achievement. It is presumably because traditional Japanese values put less emphasis on materialism. In any event, the speculation mentioned above would support the second hypothesis of the present study as far as financial success is concerned.

With regard to the relationship between educational achievement and the degree of relinquishment/embracement of Japanese values, the total category in Table VII shows that there is a strong negative correlation between these two variables. From this, one could conclude that the second hypothesis is in general supported as far as educational success is concerned. Again, it should be noted that the causation might be ambivalent.

By and large, each generation shows relatively high values of gamma when the data were differentiated by generation. To analyze these correlations, we turn to the category of educational achievement in Table VI in relation to the degree of embracement of Protestant ethic values. This is because Japanese values and Protestant ethic values were assumed to be mutually exclusive.

From Table VI and Table VII, in the case of Nisei, one could infer that higher education plays a crucial role in the acceptance (or rejection) of Protestant ethic 
values (or Japanese values). The determination whether to accept or reject may have occurred as a result of their identity dilemma. On the other hand, in the cases of Issei and Sansei, higher education did not play a significant role in embracing Protestant ethic values but it did play a critical role in rejecting Japanese values. This was salient particularly in the Sansei sample. The value of gamma $(-0.476)$ represents that $47.6 \%$ of errors can be reduced by the knowledge of one's educational background in predicting the degrees of embracement of Japanese values among the Sansei, or vice versa.

Thus, it was found that educational achievement is closely related to the formation of personal value orientation.

Our argument now proceeds to the relationship between self-judged ethnic identity and occupational, financial and educational success.

We shall start the argument from the total category of Table VIII. The total category did not show any particular correlation between these four variables. The only outcome we should note here would be the difference of the sign in the category of educational achievement. 
SELF-JUDGED ETHNIC IDENTITY BY OCCUPATION, INCOME AND EDUCATION BY GENERATION (FIGURE=GAMMA)

\begin{tabular}{lcccr}
\hline Generation & Occupation & Income & Education & N \\
\cline { 2 - 4 } Issei & 0.538 & 0 & 0.500 & 32 \\
Nisei & -0.027 & 0.025 & 0.051 & 40 \\
Sansei & 0.043 & -0.222 & -0.015 & 33 \\
\hline Total & 0.032 & -0.085 & 0.185 & 105 \\
\hline
\end{tabular}

Next, let us take a look at the values of gamma by generation. To begin with, our concern is the category of occupational achievement. The most notable relationship is the Issei's case. From this, a proposition is articulated as follows:

Among the Issei, the stronger the intensity of American identity, the greater the probability that an individual would achieve a higher level of occupational success. (Proposition 7)

This proposition would support the first hypothesis of the present study with respect to occupational success. As mentioned in Chapter III, most Issei have insulated themselves from American society by identifying with their ethnic community. With regard to this point, Kitagawa (1967: 11) has argued:

After he had lived and worked in the United States for several years, the Japanese immigrant found himself continuing to admire America as a dreamland which he might some day make his own. Physically 
he was in America, working for Americans and resting his hopes for his future in America; and yet socially (and psychologically) he was apart from the American people. He was in America but not of America. The Japanese community came to be an insulated cultural island in Anerican society, not by choice but as a result of rejection and social ostracism by American society.

Those who conformed to the Japanese community sought their occupational opportunites exclusively within the ethnic boundary. As discussed in Chapter III, Kenjinkai or other ethnic organizations played a critical role for both Japanese employers and employees to maintain their "cultural island in American society." Consequently, the Japanese community was self-contained and self-sufficient as far as their labor market was concerned.

However, in order for the community to function smoothly, it would not need too many so-called "good occupations." Rather, it required laborers for agriculture or manufacture to support its foundation. At first, some Japanese did not want to be engaged in agriculture (Kitano, 1976: 17). Later on, however, because the background of most immigrants was the farming class and also because agriculture did not require any particular investment or special skill, people gradually started turning to agriculture. As a result, the Japanese community involved a fairly large population of farmers and orchardists.

On the other hand, those Issei who did not spontan- 
eously identify with the Japanese community were obliged to seek their occupational opportunites beyond the ethnic boundary. It appears that the ethnic identity of those Issei was more American than Japanese. Also, it is assumed that a Japanese immigrant was able to obtain an occupation outside the Japanese community had he overcome the wall of acculturation by shifting his/her ethnic consciousness from Japanese to American.

of course, not all of them were successful even though their ethnic identity was American rather than Japanese. However, despite white racism, it is speculated that there were better chances in finding "good occupations" outside the Japanese community for those Issei whose ethnic identity was preponderantly American. Thus, proposition number seven should be interpreted as identity predicts occupation. By knowing a person's selfjudged ethnic identity on a one-to-ten scale, we can reduce the error of random assignment by $53.8 \%$ when predicting occupational success.

With regard to the relationship between subjective ethnic identity and financial success by generation, we could proceed in our discussion as follows. In the case of the Issei, no notable correlation was found between these two variables. There was a weak positive correlation in the Nisei sample. Finally, there was a moderately strong positive correlation in the Sansei sample. In this 
case, $22.2 \%$ of errors can be reduced when one's income is predicted by the knowledge of his/her subjective ethnic identity. This would suggest that there is a causal relationship between these two variables as shown in a proposition articulated below:

Among the Sansei, the stronger the intensity of
Japanese identity, the greater the probability
that an individual would achieve a higher level
of financial success. (Proposition 8 )

The second hypothesis of this study is rejected by this proposition. However, we would have to be careful to interpret this proposition. That is to say, there are other variables which perhaps have positive statistical association with the level of financial success. Such variables would include: his/her education, father's education, father's occupation, and social class (selfidentified). Incidentally, the values of gamma between these variables and one's financial success are shown in Table IX.

\section{TABLE IX}

STATISTICAL ASSOCIATIONS BETWEEN FINANCIAL ACHIEVEMENT AND SOME OTHER VARIABLES IN THE SANSEI SAMPLE $($ FIGURE $=$ GAMMA $)$

\begin{tabular}{|c|c|c|c|c|}
\hline Generation & Education & $\begin{array}{l}\text { Father's } \\
\text { Education }\end{array}$ & $\begin{array}{c}\text { Father's } \\
\text { Occupation }\end{array}$ & $\begin{array}{l}\text { Social } \\
\text { Class }\end{array}$ \\
\hline Sansei & 0.229 & -0.303 & 0.215 & 0.319 \\
\hline
\end{tabular}


A moderately strong correlation was found between "education" and "Japanese ID" in the Sansei sample. Consequently, a path diagram might be developed based upon a hypothetical causal structure of the set of variables as seen in Diagram 1 .

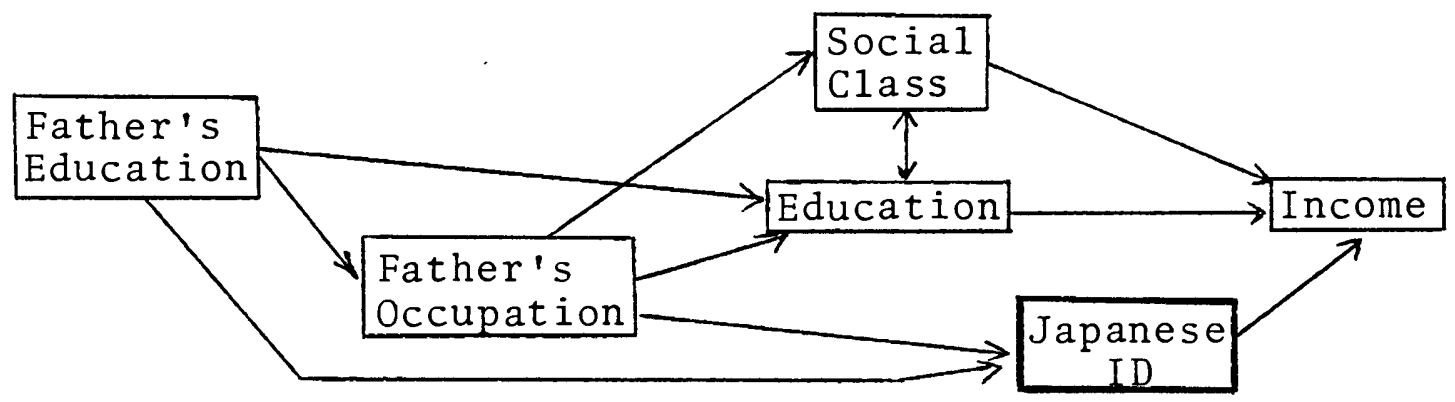

Diagram 1. Causal Relation Among the Set of Variables: A Hypothes is.

The causal relation in Diagram 1 is merely an example. It would be possible to develop other causal relations. At any rate, the important point here is to consider a particular variable as a partial cause of the presumed dependent variable. ${ }^{11}$

Finally, we proceed the argument to the correlation between self-judged ethnic identity and educational achievement by generation. From the category of educational achievement in Table VIII, a set of propositions focusing on the Issei's case is articulated as follows:

Among the Issei, the stronger the American identity, the higher the educational achievement. (Proposition 9) Among the Issei, the higher the educational achieve-

${ }^{11}$ The presumed dependent variable in Diagram 1 is 
ment, the greater the probability that an individual would preponderantly establish an American identity. (Proposition 10)

This set of propositions could also be stated in the following manner:

Among the Issei, the stronger the Japanese identity, the lower the educational achievement. (Proposition 9a)

Among the Issei, the lower the educational achievement, the greater the probability that an individual would preponderantly establish a Japanese identity. (Proposition 10a)

According to the values of gamma, $50.0 \%$ of errors can be reduced in predicting the Issei's ethnic identity by the knowledge of his/her educational background. Likewise, in the cases of $\mathrm{Nisei}$ and Sansei, the percentages of relative reduction of errors are $5.1 \%$ and $1.5 \%$ respectively. Consequently, it would suggest that in the cases of Nisei and Sansei, educational achievement is not closely related to ethnic identity.

On the other hand, educational background can be an excellent predictor of one's ethnic identity in the case of Issei (or vice versa). From this, one might speculate that education had a special function to nurture flexibility for a Japanese immigrant to shift his/her ethnic identity from Japanese to American.

Nisei and Sansei samples showed only a weak correlation. Education for the Nisei and Sansei might be an expectation regardless of their ethnic identity. Further, their parents may have determined their going to college. 
Another plausible reason appears to be related to their "marginal" experiences between Japanese and American culture. It might be argued that their "Japanese soul" has been pulling them into ambivalence no matter how much formal education they have achieved. To the Nisei and Sansei, the Issei are the people who abandoned their home country; however, like the analogy of the "banana people" or the "egg people," the Nisei and Sansei have not been able to overcome their stigma of being of Japanese descents. In particular, there is a weak positive correlation between educational achievement and Japanese identity among the Sansei sample. Thus, most Nisei and even Sansei could not identify themselves to be "complete Americans."12

Thus, the study hypotheses were supported especially by the Nisei sample. With respect to the Sansei, however, further considerations will be needed.

The Sansei were predicted to be acculturated but "not-yet-successful" due primarily to their age. In fact, the data did not show any notable correlations regarding the degree of acculturation and successfulness in the case of Sansei. However, there were a few excep-

${ }^{12}$ As shown in Table $\mathrm{V}$, the average scores of selfjudged ethnic identity were: 6.529 for the Issei with the standard deviation of $2.478 ; 5.857$ for the Nisei with the standard deviation of 1.995 ; and 4.625 for the Sansei with the standard deviation of 1.601. Note the trend in the generations from Japanese identity to American identity. 
tions. First, Proposition 5 and 6 shows a negative relationship between education and the degree of embracement of Protestant ethic values. Second, Proposition 8 showed a moderately strong positive relationship between "Japanese values" and financial success. These correlations contradict the study hypothesis. In addition to the explanations presented before, one might have to take the nature of the Sansei sample into consideration to analyze these propositions further. That is to say, those who participated in activities of ethnic organizations might possess stronger Japanese identity than those who do not.13 In other words, they appear to be more concerned with "Japaneseness." Furthermore, it might be argued that the older Sansei are likely to be the members of these organizations. If this assumption is correct, the positive relationship between Japanese identity and financial success might be explained better.

13 Note that the Sansei sample was selected from the rosters of the Japanese American Citizens' League and the Japanese American Bowling Club of Portland. It is inferred that those who are active in these organizations are less acculturated than those who are inactive. 


\section{REFERENCES FOR CHAPTER V}

Kitagawa, Daisuke

1967 Issei and Nisei: The Internment Years. New York: The Seabury Press.

Kitano, Harry H. L.

1976 Japanese Americans: The Evolution of a SubPrentice-Hall Inc. Second Edition.

Light, Ivan $\mathrm{H}$.

1972 Ethnic Enterprise in America: Business and Welfare Among Chinese, Japanese, and Blacks. Berkeley and Los Angeles, California: University of California Press.

U. S. Department of Commerce, Bureau of Census

1973 "Occupational Characteristics." 1970 Census of Population. Washington, D. C.: Government Printing office. 
CHAPTER VI

\section{CONCLUSION}

In the first chapter of this thesis, it was hypothesized that there would be four major categories with regard to the value system of the Japanese Americans. Those are: 1) those who have retained Japanese values and have adopted American values; 2) those who have retained Japanese values and have spurned American values; 3) those who have relinquished Japanese values and have adopted American values; and 4) those who have relinquished Japanese values and have spurned American values. In this typology, the use of such words as "Japanese values" and "American values" is loose; namely, the use of these words implies that they are mutually exclusive.

However, there is a congruence in the value systems between Japanese and American. Therefore, one could hypothesize that the success of the Japanese Americans is due to their successful acculturation in practicing the values which are congruent with the values of the dominant American society. Concomitantly, one could argue that the greater the congruence between these two value systems, the less likely conflict would be generated in the process of acculturation. This argument might be an indication 
for the future study.

As stated in Chapter I, the object of this study is to test the "acculturation-success theory" which has been developed throughout this thesis. This theory considers acculturation as an independent variable or a primary cause of success of the Japanese Americans. With regard to the "acculturation-success" patterns, several types were depicted in accordance with the generational categorization. Many Issei were predicted to be "notacculturated-but-successful" and some to be "not-acculturated-and-not-successful." Next, most Nisei were predicted to be "acculturated-therefore-successful." Finally, the Sansei were predicted to be "acculturated-but-not-yetsuccess ful."

"Acculturation" is thus the key concept in this study in relation to "successfulness." Regarding successfulness, three aspects have been articulated: occupational, financial and educational success. Both occupational and financial success were in this study treated as dependent variables in the causal relation with the degree of acculturation. Acculturation, then, was treated as a presumed cause of success.

With regard to educational success, however, it was hypothesized that the causal direction may run either way. Education was on the one hand hypothesized to be an independent variable affecting acculturation; on the other 
hand, education was also hypothesized to be a dependent variable affected by acculturation.

The findings in Chapter $V$ would suggest that an individual would be successful if he/she has retained the compatible values and/or relinquished the incompatible ones, particularly in the case of the Nisei. The arguments in Chapter $V$ would also suggest that educational achievement is closely related to one's value orientation. That is, one might be able to conclude that the degree of acculturation is significantly influenced by or influencing the level of educational achievement.

The return rate of $38.0 \%$ might not be high enough to make a conclusion here. In addition, sample was selected from the rosters of ethnic organizations which were highly self-selected groups. These aspects might have jeopardized the validity of the results of this study. However, one could not deny the important impact of those organizations on the Japanese Americans as a whole. Therefore, the writer wishes that the analysis of those group members be a stepstone to a future study of the Japanese Americans.

Lastly, the writer would like to conclude with another set of findings as an implication for the future study. That is, there were particular values which showed strong correlations with the level of occupational, financial and educational success. Among these values which showed 
positive correlations are: individuality with occupational success; success, willingness to sacrifice today for the gain in the future, and ambition with financial success; and freedom with educational success. Interestingly enough, these values are all associated with the American value system. On the other hand, there were values which showed negative correlations with the aspects of success. These values include: respect for the Emperor and obedience with occupational success; respect of ancestors and good personal relation with financial success; and proper behavior in accordance with one's $\underline{\text { status }}$ and respect for one's superior with educational success. All but one ("good personal relation") is associated with the traditional Japanese values in this case. Although particular suggestions could not be made from this, it might be inferred that success orientation is linked strongly with the Protestant ethic which stresses individualism. Moreover, it appears that success orientation could not be nurtured by traditional Japanese values which stress the harmonious stability of society. 


\section{BIBLIOGRAPIYY}

Albert, Ethel $\mathrm{M}$.

1956 "The Classification of Values: A Method and

Illustration." American Anthropologist

58: $221-48$.

Arkoff, Abe

1959 "Need Patterns in Two Generations of JapaneseAmericans in Hawaii." The Journal of Social Psychology 50: 75-9.

Gerald M. Meredith and Shinkuro Iwahara

1962' "Dominance-Deference Patterning in Motherland Japanese, Japanese-American, and CaucasianAmerican Students." The Journal of Social Psychology 58: 61-6.

1964 "Male-Dominant and Equalitarian Attitudes in Japanese, Japanese-American, and CaucasianAmerican Students." The Journal of Social Psychology 64: 225-9.

Babbie, Earl R.

1973 Survey Research Methods. Belmont, California: Wadsworth Publishing Company, Inc.

Benedict, Ruth

1946 The Chrysanthemum and the Sword: Patterns of Japanese Culture. New York: New American Library.

Bonacich, Edna

1973 "A Theory of Middleman Minorities." American Sociological Review 38 (October): 547-59.

Bosworth, Allan R.

1967 America's Concentration Camps. New York: W. W. Norton and Company.

Caudil1, William

1952 "Japanese-American Personality and Acculturation." Genetic Psychology Monographs 45: 3-102. 
Chuman, Frank F.

1976 The Bamboo People: The Law and Japanese Americans. Del Mar, California: Publisher's Inc.

Cohen, Albert $\mathrm{K}$.

1955 Delinquent Boys: The Culture of the Gang.

Glencoe, Illinois: The Free Press.

Davies, Peter, Ed.

1977 The American Heritage Dictionary of the English Language. Paperback Edition. New York: De11 Publishing Co., Inc.

DeVos, George

1955 "A Quantitative Rorschach Assessment of Maladjustment and Rigidity in Acculturating Japanese Americans." Genetic Psychology Monographs

52: $\quad 51-87$.

Dore, Ronald P.

1958 City Life in Japan: A Study of a Tokyo Ward. Berkeley and Los Angeles; California: University of California Press.

Gordon, Milton M.

1964 Assimilation in American Life: The Role of Race, Religion, and National Origins. New York: oxford University Press.

Gulick, S. L.

1914 The American Japanese Problem. New York: Charles Scribner's Sons.

Hodge, John L., Donald K. Struckmann and Lynn D. Trost

1975 Cultural Bases of Racism and Group Oppression: An Examination of Traditional "Western" Concepts, values and Institutional Structures Which Support Racism, Sexism and Elitism. Berkeley, California: Two Riders Press.

Hosokawa, Bill

1969 Nisei: The Quiet Americans. New York: William Morrow and Company, Inc.

Hraba, Joseph

1979 American Ethnicity. Itasca, Illinois: F. E. Peacock Publishers, Inc. 
Ichihashi, Yamato

1932 Japanese in the United States: A Critical Study of the Problems of the Japanese Immigrants and Their Children. Stanford Univer sity, California: Stanford University Press.

Iga, Mamoru

1966

"Changes in Value Orientations of JapaneseAmericans." Quoted in Harry H. L. Kitano, Japanese-Americans: The Evolution of a Subculture. (1976: Second Edition). New Jersey: Prentice-Hall.

Kitagawa, Daisuke

1967 Issei and Nisei: The Internment Years. New York: The Seabury Press.

Kitano, Harry H. L.

1976a Japanese Americans: The Evolution of a SubPrentice-Hal1, Inc. Second Edition.

1976b "Japanese Americans: The Development of a Middleman Minority." In Norris Hundley, Jr., ed., The Asian Americans: The Historical Experience. Santa Barbara, California: Clio Press.

Kluckhohn, Clyde

1951 "Values and Value-Orientations in the Theory of Action." In Talcott Parsons and Edward A. Shils, eds., Toward a General Theory of Action. Massachusetts: Harvard University Press. $388-433$.

Kluckhohn, Florence R. and Fred L. Strodtbeck

1961 Variations in Value Orientations. Evanston, IIIinois: Row, Peterson and Company.

Light, Ivan $\mathrm{H}$.

1972 Ethnic Enterprise in America: Business and Welfare Among Chinese, Japanese, and Blacks. Berkeley and Los Angeles, California: University of California Press.

Marden, Charles F. and Gladys Meyer

1978 Minorities in American Society. New York:

D. VanNostrand Company. Fifth Edition.

McWilliams, Carey

1944 Prejudice: Japanese-Americans, Symbol of Racial Intolerance. Boston, Massachusetts : Little, Brown and Company. 
Meredith, Gerald M. and Connie G. W. Meredith

1966 "Acculturation and Personality Among JapaneseAmerican College Students in Hawaii." The Journal of Social Psychology 68: $175-8 \overline{2}$.

Merton, Robert $K$.

1968 Social Theory and Social Structure. New York: The Free Press. 1968 Enlarged Edition.

Myer, Dillon S.

1971 Uprooted Americans: Japanese Americans and the War Relocation Authority During World War II. Tucson, Arizona: University of Arizona Press.

Nie, Norman H., et al.

1975 Statistical Package for the Social Sciences. New York: McGraw-Hill Book Company.

Parsons, Talcott

1951 The Social System. New York: The Free Press. Paperback Edition.

1962 "Youth in the Context of American Society." In his Social Structure and Personality (1970). New York: The Free Press.

and Edward A. Shils

1951 Toward a General Theory of Action. Cambridge, Massachusetts: Harvard University Press.

and Robert F. Bales 1955 Family, Socialization and Interaction Process.

Petersen, William

1966 "Success Story, Japanese-American Style." The New York Times Magazine (January 9): 20-43.

1971 Japanese Americans: Oppression and Success. New York: Random House, Inc.

Reischauer, Edwin 0.

1977 The Japanese. Cambridge, Massachusetts: Harvard University Press.

Reiss, Jr., Albert J.

1961 Occupations and Social Status. New York: The Free Press. 
Riesman, David with Nathan Glazer and Reuel Denney 1961 The Lonely Crowd: A Study of the Changing American Character. New Haven, Connecticut: Yale University Press. Abridged Edition.

Schwartz, Audrey J.

1971 "The Culturally Advantaged: A Study of JapaneseAmerican Pupils." Sociology and Social Research 55 (Summer): 341-51.

Stein, Jess and P. Y. Su., eds.

1978 The Random House Dictionary. New York: Ballantine Books.

Strong, Jr., Edward K.

1934 The Second-Generation Japanese Problem. Stanford University, California: Stanford University Press.

Theodorson, George A. and Archilles G. Theodorson

1969 A Modern Dictionary of Sociology. New York: Barnes and Noble Books.

Thomas, William I. and Florian Znaniecki

1918 The Polish Peasant in Europe and America. New

York: Dover Publications.

U. S. Department of Commerce, Bureau of Census

1973 "Japanese, Chinese, and Filipinos in the United States." 1970 Census of Population. Washington, D. C.: Government Printing Office.

1973 "Occupational Characteristics." 1970 Census of Population. Washington, D.C.: Government Printing Office.

1976 Statistical Abstract of the United States: 1976. Washington, D. C.: Government Printing Office.

Varley, H. Paul

1973 Japanese Culture: A Short History. Tokyo: Charles E. Tuttle Company.

Weber, Max

1958 The Protestant Ethic and the Spirit of Capitalism. Translated by Talcott Parsons. New York: Charles Scribner's Sons. Originally published in German in 1904-5. 
Williams, Jr., Robin M.

1970 American Society: A Sociological Interpretation. New York: Alfred A. Knopf, Inc. Third Edition. (First Edition in 1951; Second Edition in 1960. ) 


\section{APPENDIX}

\section{Appendix A: Selected Values For The Value Question}

A. Traditional Japanese Values

* 1. Filial duty

* 2. Respect for one's superior

* 3. Worship of ancestors

* 4. Feeling of togetherness with one's clan

* 5. Respect for the Emperor

* 6. Obedience

7. Credit to the family name

8. Faithfulness to one's duty

9. Prudence

10. Patience

11. Generosity

12. Appreciation of human feelings

13. Proper behavior in accordance with one's status

14. Repayment of kindness which one received in the past

** 15. Credit to one's own name.

* * 16. Educational achievement

** 17. Work as a virtue

**18. Success

* 19. Courteousness

** 20. Self-discipline

* 21. Self-control

** 22. Asceticism (including "industry" and "thrift")

*The values which are incongruent with the American middle-class value system derived from the Protestant ethic.

**The values which are congruent with the American middle-class value system.

B. Traditional American Middle-Class Values

1. Ambition

2. Individuality

3. Rationality

4. Good personal relation

5. Improvement 
6. Pursuit of a hobby

7. Responsibility for one's conduct

8. Respect for property

9. Respect for authority

10. Freedom

11. Humanitarianism

12. Willingness to sacrifice today for the gain in the future

* 13. Credit to one's own name

* 14. Educational achievement

* 15. Work as a virtue

* 16. Success

* 17. Courteousness

* 18. Self-discipline

* 19. Self-control

* 20. Asceticism (including "industry" and "thrift")

* The values which are congruent with the traditional Japanese value system.

Appendix B: The Introductory Letter For The Questionnaire

January 7,1980

Dear friend:

My name is Toshimasa Fujii; and I am a candidate for the degree of Master of Arts in Sociology at Portland State University. I am now working on my master's thesis entitled A Study of the Degree of Acculturation in Three Generations of Japanese Americans of the Portland Area (Tentative).

The purpose of this study is to find out the reason why the Japanese Americans have been called as a "successful minority group" in the United States. In order to complete this study, your participation in a completion of the attached questionnaire is essential. Therefore, your cooperation will be greatly appreciated.

Please send back the completed questionnaire by January 16, 1980, using the enclosed self-addressed envelope.

Thank you very much,

Sincerely yours,

Signature

Toshimasa Fujii 
Appendix C: The Cover of The Questionnaire

\author{
PORTLAND STATE UNIVERSITY \\ Department of Sociology
}

\begin{abstract}
A STUDY OF THE DEGREE OF ACCULTURATION IN THREE GENERATIONS
OF JAPANESE AMERICANS OF THE PORTLAND AREA
\end{abstract}

As a part of the thesis project of

Toshimasa Fujii (A candidate for the degree of M. A. in Sociology)

Under the supervision of

Prof. Frederic H. Chino, Ph. D.,

Prof. Jan Hajda, Ph. D., and

Prof. Grant M. Farr, Ph. D.

\title{
Explanation and Instructions
}

1. There are no right or wrong answers to the questions in this questionnaire.

2. The only "right" answer to each question is the one which best applies to you.

3. Your participation in this study is completely voluntary.

4. Your responses will be kept strictly confidential.

5. If you have any questions regarding this study, call or write:

Toshimasa Fujii

Department of Sociology

Portland State University

Portland, Oregon 97207

Home Telephone: 224-9210

Thank you for your help in this study! 
Appendix D: The Questionnaire

A. Questions About Your Background

1. What is your age?

2. What is your sex?

Male

Female

3. What is your generation?

Issei (First generation, immigrant from Japan)

Nisei (Second generation, born in America)

Sansei (Third generation of Japanese ancestry) other

Please specify (For example: Father-Issei, Mother-Nisei; or Father-Caucasian American, Mother-Issei;etc.) :

4. If you are an Issei,

a) Which prefecture of Japan are you from?

b) How long have you lived in the U.S.?

5. What is your present marital status?

Married Single Widowed Divorced

6. Which of the following best describes your working status?

Working full time

Working part time Unemployed or laid off Keeping house
Retired

other

Please specify:

7. If you are married, which of the following best describes your spouse's working status?

Working full time

Working part time Unemployed or laid off Keeping house
Retired

Other

Please specify:

8. What kind of occupation are you currently engaged in? Be specific please. (For example, teacher of English in a high school or supervisor of electronics quality control.) 
9. What kind of occupation is your father currently engaged in? If your father has been retired or is not alive, what was his last occupation? Be specific please like the example in the question \#8.

10. What is currently the average total annual income before taxes of your family? Please check the most appropriate category.

Less than 2,500

2,500 to 4,999

5,000 to 7,499

7,500 to 9,999

10,000 to 12,499

12,500 to 14,999

15,000 to 17,499

17,500 to 19,999

20,000 to 24,999

25,000 to 29,999
30,000 to 34,999

35,000 to 39,999

40,000 to 44,999

45,000 to 49,999

50,000 to 54,999

55,000 to 59,999

60,000 to 64,999

65,000 to 69,999

70,000 to 74,999

75,000 and over

11. What is (was) the average total annual income before taxes of your parents? Even if you do not know precisely, please make a guess as to the closest figure. Please check the most appropriate category.

Less than 2,500

2,500 to 4,999

$-5,000$ to 7,499

7,500 to 9,999

10,000 to 12,499

12,500 to 14,999

15,000 to 17,499

17,500 to 19,999

20,000 to 24,999

25,000 to 29,999
30,000 to 34,999

35,000 to 39,999

40,000 to 44,999

45,000 to 49,999

50,000 to 54,999

55,000 to 59,999

60,000 to 64,999

65,000 to 69,999

70,000 to 74,999

75,000 and over

12. How certain are you of your answer to question \#11?

Very certain

Fairly certain

Somewhat certain

Uncertain

It's just a guess 
13. How much formal education have you and your parents completed? Please check all that apply.

Your- Step Step

self Father Mother Father Mother

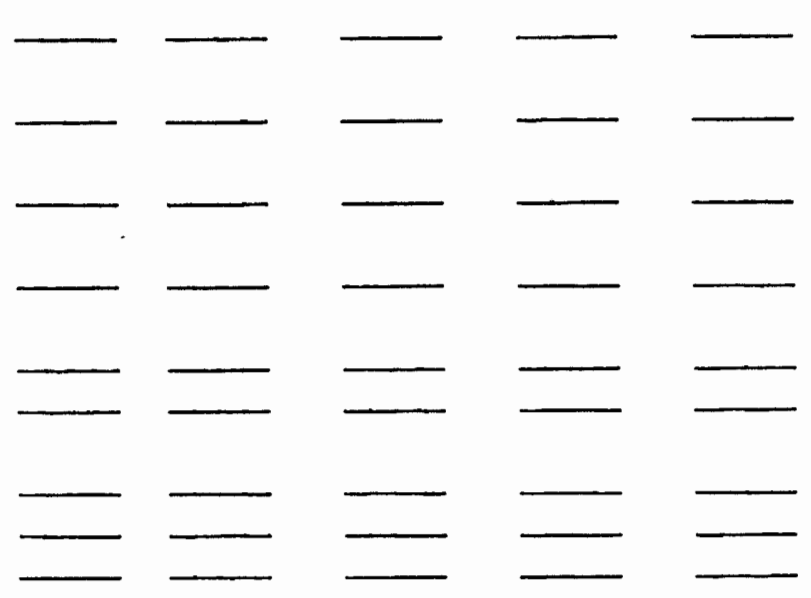

No formal education Some elementary school Completed elementary school Some junior high school Completed junior high school Some high school Completed high school

Some college

Completed college Post graduate work, but no advanced degrees

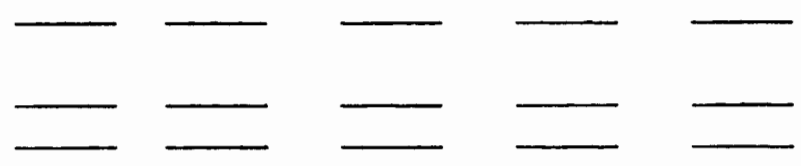
One or more graduate degrees

I am not at all sure

14. If you or your parents had some college or more education, what kind of college was that? (For example: regular liberal arts college; dental college; business college; beauty college; etc.)

Yourself

Father

Mother

Stepfather

Stepmother

15. What is the religious preference of you and your parents? Be as specific as possible please. (For example: Shinto; Buddhism of the Jodo sect; Roman Catholic; Baptist; etc.)

Yourself

Father

Mother Stepfather Stepmother 
16. Are you currently a member of any ethnic organization?

Yes

No

17. If you answered "Yes" to the above question,

a) What kind of organization is it? and

b) How often do you participate in the organization activity?

Please check all that apply.

Nikkeijinkai (The Japanese Ancestral Society or JAS)

Never attend

Attend, but less than once a month

About once or twice a month

Three, four or more times a month

Nikkei Fujinkai (The Japanese Ancestral Women's Club or JAWC)

Never attend

Attend, but less than once a month

About once or twice a month

Three, four or more times a month

The Japanese American Citizen's League or JACL

Never attend

Attend, but less than once a month

About once or twice a month

Three, four or more times a month

Other (Please specify:

Never attend

Attend, but less than once a month

About once or twice a month

Three, four or more times a month 
18. How many Japanese or Japanese Americans are there in your neighborhood? (Consider 'neighborhood' to mean the area within a walking distance of your home.) Please check the most appropriate category.

None
-1 to 5
-6 to 10
-11 to 15
-16 to 20
21 or more

19. Broadly speaking, do you think you have more Japanese or Japanese-American friends than CaucasianAmerican friends?

Yes Approximately half and half No

20. Which social class do you think you belong to? Please check the most appropriate category.

\begin{tabular}{l} 
Upper class \\
\hline Upper middle class \\
Lower middle class \\
Working class \\
Lower class
\end{tabular}

21. Let us assume that on a scale of one-to-ten, a complete Japanese identity be given a value of 10 and a complete American identity a value of 1 . Indicate the number which in your judgement most closely describes your ethnic identity.

\section{B. Questions About Your Opinions (Part One)}

In this section, questions about your opinions to thirty-four words or phrases will be asked. Those words or phrases considered to be "values" or "standards of behavior." Please check the category that best applies to you.

1. Rationality

Very Important

Important

Somewhat Important

Somewhat Unimportant Unimportant
2. Patience

Very Important Important Somewhat Important Somewhat Unimportant Unimportant 
3. Repayment of

kindness which one received in the past

Very Important

Important

Somewhat Important

- Somewhat Unimportant Unimportant

4. Prudence

Very Important

Important

Somewhat Important

Somewhat Unimportant Unimportant

5. Asceticism (including "industry" and "thrift")

Very Important

Important

Somewhat Important

Somewhat Unimportant Unimportant

6. Worship of ancestors

Very Important

Important

Somewhat Important

Somewhat Unimportant Unimportant

7. Individuality

Very Important

Important

Somewhat Important

Somewhat Unimportant Unimportant

8. Respect for authority

Very Important

Import ant

Somewhat Important

Somewhat Unimportant Unimportant
9. Filial duty

Very Important

Important

Somewhat Important

Somewhat Unimportant Unimportant

10. Respect for one's. superior

Very Important Important

Somewhat Import'ant Somewhat Unimportant Unimportant

11. Rursuit of a hobby

Very Important Important Somewhat Important Somewhat Unimportant Unimportant

12. Courteousness

Very Important Important Somewhat Important Somewhat Unimportant Unimportant

13. Appreciation of human feelings

Very Important Important Somewhat Important Somewhat Unimportant Unimportant

14. Educational achievement Very Important Important Somewhat Important Somewhat Unimportant Unimportant 
15. Freedom

Very Important Important Somewhat Important Somewhat Unimportant Unimportant

16. Self-discipline

Very Important Important Somewhat Important Somewhat Unimportant Unimportant

17. Responsibility for one's conduct

Very Important

Important

Somewhat Important

Somewhat Unimportant Unimportant

18. Ambition

Very Important Important Somewhat Important Somewhat Unimportant Unimportant

19. Credit to one's own name

Very Important

Important

Somewhat Important

Somewhat Unimportant Unimportant

20. Success

Very Important Important

Somewhat Important Somewhat Unimportant Un important
21. Credit to the family name

Very Important

Important

Somewhat Important

Somewhat Unimportant Unimportant

22. Feeling of togetherness with one's clan

Very Important Important

Somewhat Important Somewhat Unimportant Un important

23. Improvement

Very Important Important Somewhat Important Somewhat Unimportant Unimportant

24. Willingness to sacrifice today for the gain in the future

Very Important Important

Somewhat Important Somewhat Unimportant Unimportant

25. Good personal relations Very Important Important Somewhat Important Somewhat Unimportant Unimportant

26. Self-control

Very Important

Important

Somewhat Important

Somewhat Unimportant Unimportant 
27. Humanitarianism

Very Important

- Important

- Somewhat Important

Somewhat Unimportant

Unimportant

28. Respect for property

Very Important

Important

Somewhat Important

Somewhat Unimportant Unimportant

29. Respect for the Emperor

Very Important

Important

Somewhat Important

Somewhat Unimportant Unimportant

30. Obedience

Very Important

Important

Somewhat Important

Somewhat Unimportant Unimportan $t$
31. Generosity

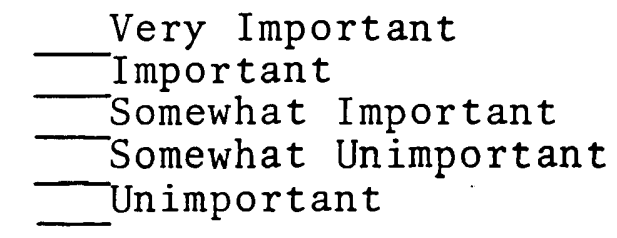

32. Work as a virtue

Very Important

- Important

Somewhat Important

Somewhat Unimportant Unimportant

33. Proper behavior in accordance with one's status

Very Important Important Somewhat Important Somewhat Unimportant Unimportant

34. Faithfulness to one's duty

Very Important Important

Somewhat Important

Somewhat Unimportant Unimportant

C. Questions About Your Opinions (Part Two)

Like Part One, please check the category that best applies to you.

1. Generally speaking, one should restrain his/her emotion to maintain good personal relations.

Agree completely

Tend to agree

Neutral

Tend to disagree

Disagree completely 
2. One should be willing to sacrifice his/her private time for the sake of the group to which he/she belongs. (For example: company, church, family, etc.)

Agree completely

Tend to agree Neutral

Tend to disagree

Disagree completely

3. One should always favor one's own relatives.

Agree completely

Tend to agree

Neutral

Tend to disagree

Disagree completely

4. Comparatively speaking, one should be judged on

the basis of "what he/she has done" rather than on the basis of his/her inborn qualities (such as sex, age, race, or family status).

Agree completely

Tend to agree

Neutral

Tend to disagree

Disagree completely

5. One should limit the number of his/her "close friends" in relatively small number.

Agree completely

Tend to agree

Neutral

Tend to disagree

Disagree completely

That's all. Thank you very much! 
Appendix E: The Follow-Up Letter

$$
\text { January } 17,1980
$$

Dear friend:

Recently, you were sent a questionnaire requesting your participation in a study concerning the degree of acculturation of Japanese Americans. I apologize for sending this if you have completed and sent back the questionnaire. I am sending this to emphasize that the validity of the research findings depends upon your cooperation.

I would appreciate your completing and sending back the questionnaire even though the dead line I requested (1/16) has passed.

$$
\begin{aligned}
& \text { Yours sincerely, } \\
& \text { Signature } \\
& \text { Toshimasa Fujii }
\end{aligned}
$$

P. S. If any question arises, please call 224-9210. 


\section{Appendix F: The Introductory Letter--Japanese Version}

\section{一世の皆样へ。}

㒸略。

私はポートランド州立大学の大学院生ですが。二のたでポート ランド近郊在住の日系アメリカ人の屯代间における「文化变容山 に奥する社会調查を实施することとなりました。二の調查の目的 は.なぜ日系アメ门カ人がアメリカ社会における「成功した少数 民族集团」と言和れているのかを解き明か光うとするものです。 二の調查を完成させる為には皆栚の御意見をこのアンケート調 查を通じ々お伺いする事が是非とも必要であり、皆様加らの返答 はとても貴重なものとなります。

記入したアンケートは同封の住所が書かれ切手の貼られた封筒 を使っマ、なるべく一立十六日までに投逐して下さいますようよ ろしくお願いします。

なお、二のアンケート調査は、二屯およで三屯の方々についマ は英語で行なわれます。

一兀ハ0年一月七日.

敬具

藤井敏雅

Appendix G: The Cover of The Questionnaire--Japanese Version

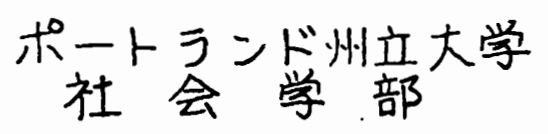

$$
\begin{gathered}
\text { ポートランド近郊在住の日系アメリカ人の } \\
\text { 三击代间における文化变容程度に } \\
\text { 送する研究 }
\end{gathered}
$$


もので下記教授の指真・監修によるものです。

Frederic H. Chino 敨授 (哲学博士).

Jan HaJda 教授(哲学博士) 及で

Grant M. Farr 教授 (垫学博士)。

一一説明ならでに記入にあたっての注意

一。各古いに対する答には正しいとか闲違っていると いうよう后ものはありません。

二、最も自分に適した答が关机资れの古いに「ふされ しい」答ということになります。

三。のの研案にあすたが参加するかしないかはあなた の自主的应判断によるものです。

四、あなたの回答は䈯重に機密事項として保疜されま व。

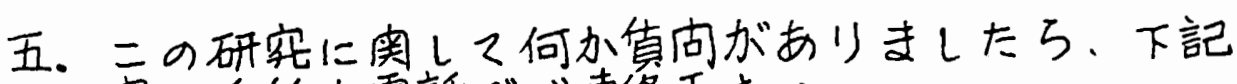
宛に手紙か電話でニ゙連絡下さい。

Toshimasa Fujii

Department of Sociology

Portland State University

Portland, Oregon 97207

Home Telephone: 224-9210

御協力ありがとうございます！ 


\section{Appendix H: The Questionnaire--Japanese Version}

\section{A。あなたの経歷に阐する筫问}

1。あなたは現在何歲ですか？

2、あなたは男性ですか、告れとも女性ですか？一男一女

3.あなたの屯代は？

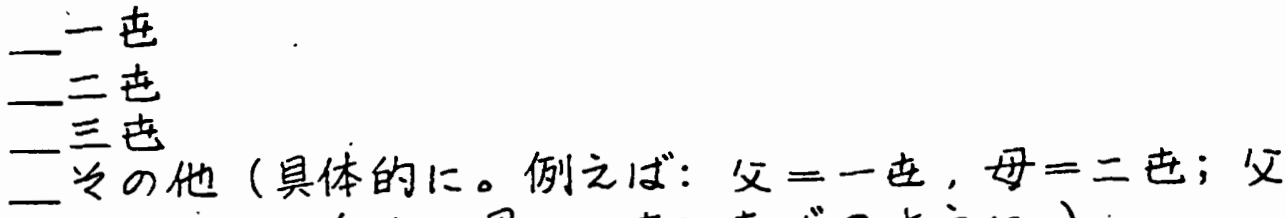

$$
\begin{aligned}
& \text { 白人，母=一世；な゙のように。) }
\end{aligned}
$$

4.もしあなたが一せなら，

2)あなたは日本の何県の出身ですか？

b)あなきはメリカにどの位長く住んぞいますか？

一私は一老ではありません。

5。あなたは次のどれにあたりますか？

一結婚中一独身一伴倡々死別一離婚中

6.あなたは次のどれにあたりますか？

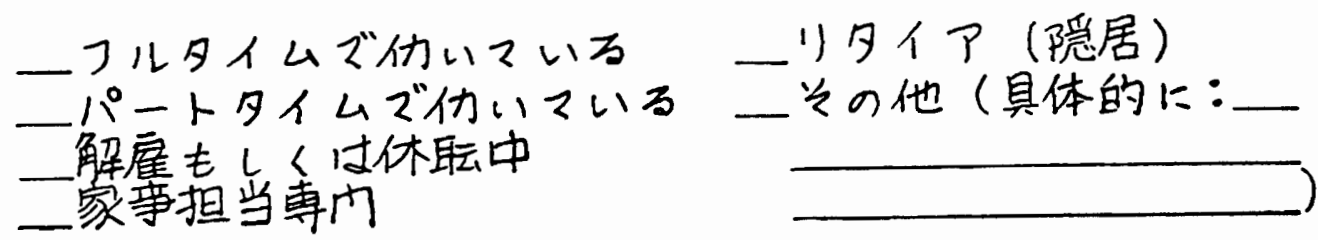

ア、もしあなたが結婚中なら，あなたの配偶者（伴侣）小次の どれにあたりますか？

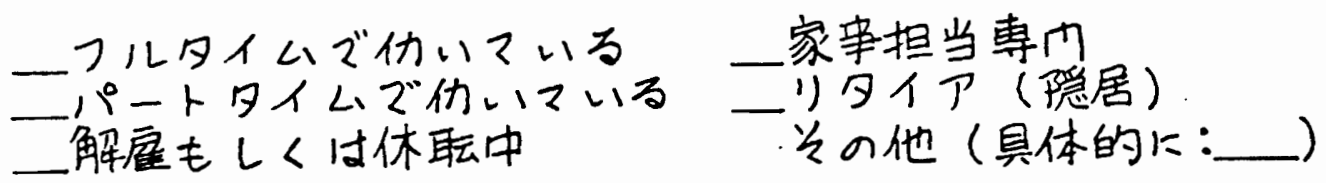


8.あなには現在どのような仕事に就いていきすか？具体的

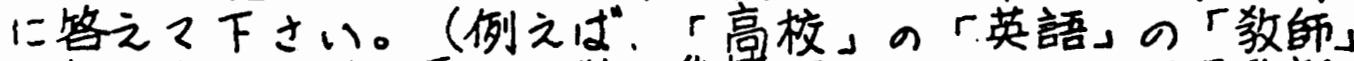
とか。あるいは「電子工学品真管理」における「現場監督」 などというようにお願いします。)

9.あなたのお父さんは現在どのような仕事に就いていますか？ もしあなたのお父さんがすでにりタイアあるいは死去して いる場合。お父さんの最後の仕要何でしたか？间8の 例のように具体的者现で答之マ下きい。

10.あなたの家庭の税引き羊の年间総収入は次のじれにあたり ますか? (単位: ドル)

Less than 2,500

2,500 to 4,999
$-5,000$ to 7,499
7,500 to 9,999
$-10,000$ to 12,499
$-12,500$ to 14,999
15,000 to 17,499
$-17,500$ to 19,999
$-20,000$ to 24,999
$-25,000$ to 29,999

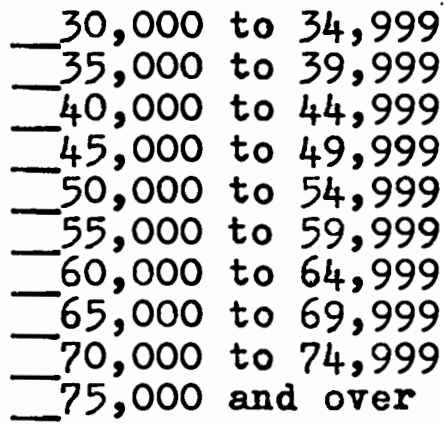

11.あなたの両親の税引き羊の年间統収入は次のどれにあたり ますか? 正確額がわからすくマも最も近いと思われる 額を推剘しマ下さい。(单位：ドル)

Less than 2,500
$-2,500$ to 4,999
$-5,000$ to 7,499
$-7,500$ to 9,999
$-10,000$ to 12,499
$-12,500$ to 14,999
$-15,000$ to 17,499
$-17,500$ to 19,999
$-20,000$ to 24,999
$-25,000$ to 29,999

30,000 to 34,999
$-35,000$ to 39,999
$-40,000$ to 44,999
$-45,000$ to 49,999
$-40,000$ to 54,999
$-55,000$ to 59,999
$-60,000$ to 64,999
$-65,000$ to 69,999
$-70,000$ to 74,999
$-75,000$ and over

12.あなたの古いに対する喆はどの位確かなものですか？ 
非常に確か

加な確か

少しだけ確か

不確六

単なる推則にすぎい

13.あなたとあなたの雨親の学歴は次のどれにあたりますか？ 故柏身 父親 母親 継父 継母

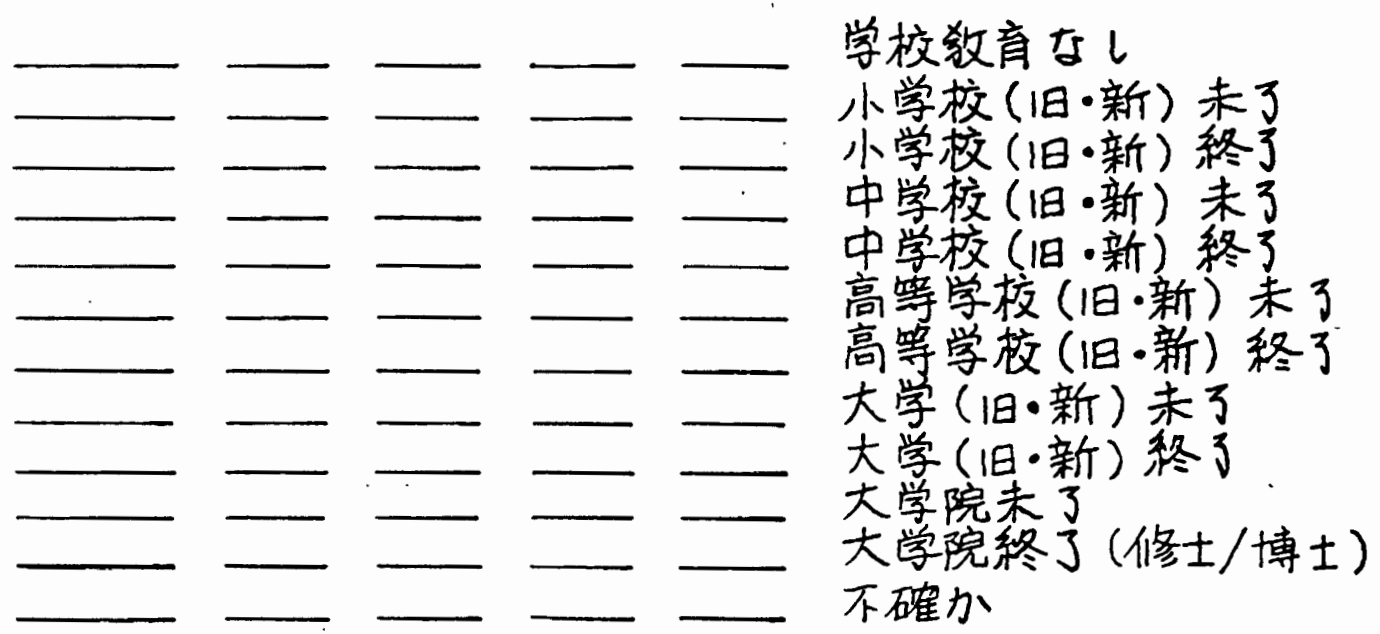

14.もしあなたもしくはあなたの(両)親が大学教育を受けて いたなら。之れはどんな種類の大学でレたか?

（例えば:

普通の四年制大学; 短期大学; 歯科大学; 医科大学; ビジ

ネス・カレッジ;ビューティ・カレッジ；等々)

根店自身

文 親

母 親

継 父

継 女

15.あなたとあなたの而親の宗教は何ですか？出来るだけ貝 体的に客之マF之い。(例えば：神道; 禅宗仙数; 浄土宗 仏放; キリスト数二ローマ・カトリック派; キリスト教二 バプテスト派，等々)

㚴三自身

文 親

母 親 


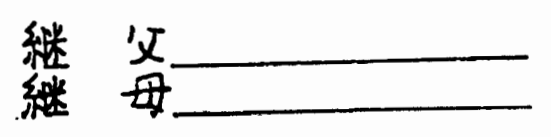

16.あなたは目下何かの「会」に加入していますか?

$$
\text { 一はいーいいえ }
$$

17.もしあなたが上の南いに「はい山と答えたなら。

a)兰ればんな団体ですか？

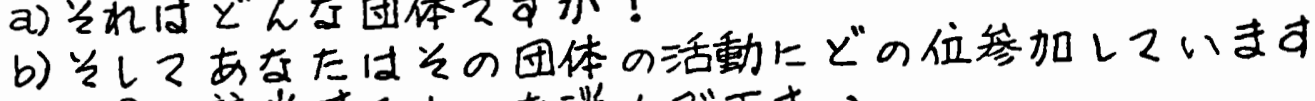
か？ 該当するものを迷んで下きい。

一日系人会 (J.A.S.)

全く参加しない

一弆加するがーケ月に一回より少ない

一大体一っ月に一回か二回

二一ヶ月上三，四回加れ以上

一日系婦人会 (J.A.W.C.)

一全く参加しをい

一参加するがーワ月に一回より少ない

二大体一ク月に一回か二回

二一っ月に三，四回名机以上

一日系アメリ力市民連盟 (J.A.C.L.)

全く参加しない

一參加するがーヶ月に一回より少ない

一天体一邱一一回か二回

二一ヶ月上三，四回か之れ以上

一学の他（具体的に:

一全く篹加しない

一參加するがーヶ月に一回より少をい

二天体一ヶ月に一回か二回

一ーク月上，四回か之水以上

18. あをたの家の近所に日本人か日系アメリ力人日向人位住ん でいますか（「近所」とはあをたの家から歩いて行か れる蓖用と考えて下さい。

$-1 \sim 5$ 人 


$$
\begin{array}{r}
6 \sim 10 \curlywedge \\
-11 \sim 15 \hat{\gamma} \\
-16 \sim 20 \curlywedge \\
-21 \text { 人以上 }
\end{array}
$$

19.大まかに言っマあなたは日本人か日系アメリカ人の友人の 方が、白人の友人より多いですか?

$$
\text { 一はい 一大体半R 一いい之 }
$$

20.社会におけるあをたは次のどの階層にあたると思いますか？

上流階䄲

中流崉級の上

中㐬崉級の下

学仂者階級

一下層階級

21. 1 から10までの「尺度山を仮定し，完全寺日本人が「1」

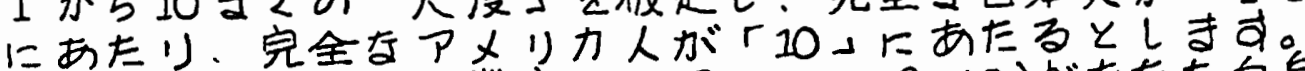

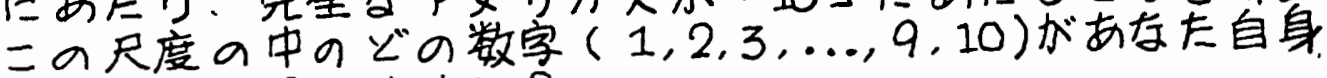
にあたると思いますか？

\section{B.あなたの意見に咸する賁冏（为一部）}

ニの部门2゙は34の言葉や言い回しに对するあなたの意見が Eず称られます。机水らの言葉や言い回しは「価值観」とか 行動の規範」と呼ばれるものです。あるたがもっともふさ わしいと思うものに㭌(レ)をつけマ下さい。

1. 合理性

ーとそも重要

重要

二やや重要 あまり重要でない 重要で年い
2. 忍酎

一๖マも重要

二重要 やや重要

一あまり重要でない 重要でをい 
3. 思返し

ーとても重要

重要

二やや重要

二あまり重要でない 重要ですい

しり上ふんベっ

4. 思虍分別

と2も重要

重要

二やや重要

あまり重要でない 重要でない

5. 勤勉及で険約

一ะ2も重要

二重要

一やや重要

一あまり重要でない 重要でない

6. 祖先崇拝

一とそも重要

一重要

二やや重要 あまり重要でない 重要でない

?. 個性

と2も重要

重要

やや重要

一あまり重要でない 重要でをい
8. 權力(者) に対する敬意

一とても重要

重要

やや重要

あまり重要でない

重要でをい

9. 親孝行

ーとマも重要

二重要

二やや重要

二あまり重要でない 重要でをい

10. 目上の者に対する敬意

一とそも重要

重要

一やや重要 あまり重要でをい 重要でない

11. 趣味の追究

ーとても重要

二重要

や丸重要

あまり重要でない 重要でない

12. 礼儀作法

ーとマも重要 重要 やゃ重要 あまり重要でない 重要でない 
13.人情を解する事

\section{ーとマも重要}

\section{重要}

やや重要

一あまり重要でない 重要でない

14. 学校教育

ーとマも重要

一重要

二やや重要

二古まり重要でない 重要でない

15. 自由

一とそも重要

二重要 也㙘要

一あまり重要でない 重要でない

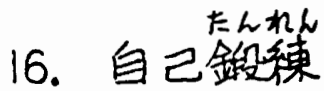

一とそも重要

重要

二やや重要

二あきり重要でない 重要认゙ない
18.野心あるいは大志

一とマも重要

重要

一やや重要

二あまり重要でをい 重要でない

19. 自分の名前に対する信用

一とマも重要

重要

二やや重要

一あまり重要でない 重要でない

20. 成功

$$
\begin{aligned}
& \text { ーとマも重要 } \\
& \text { 重要 } \\
& \text { や出重要 }
\end{aligned}
$$

21. 家の名上对する信用

一とそも重要

二重要

二やや重要

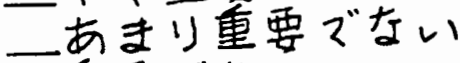
重要ですマ

17. 自分の行動に対する青任 22 自分の親類との連带感

一とても重要

二重要 やゃ重要 あまり重要でない 重要でをい

一とスも重要

一重要

やや重要

一あきり重要でない 重要でない 
23. 向上心

ーとそも重要

重要

一やや重要

あまり重要でをい 重要でをい

24. 捋来の為に現在を儀性に
する事

一とマも重要

二重要

やや重要

二亦まり重要ですい 重要でない

25. 良い対人成係

一とマも重要

重要

やや重要

克まり重要でない

重要ですい

26. 自己統制

ーとスも重要

二重要 やゃ重要

二あまり重要ですい 重要で左い

27.人道 (博受) 主厍

ーとマも重要

重要

やや重要

あまり重要でない 重要でをい
28、持ち物を大切にする事

一とマも重要

重要

二やや重要 あまり重要でない 重要でない

29. 天皇尊敬

一とても重要

重要

二かか重要

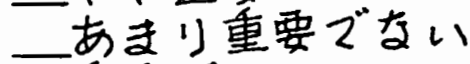
重要ですい

30. 従順

一とても重要 重要 やわ重要 ああり重要でない 重要ですい

31. 寛容

一とても重要

一重要 やゃ重要

一古まり重要でない 重要でをい

32. 仂ら<事

一关そも重要 重要 やゃ重要

二あまり重要でない 重要でない 
33.身分相応なふるまい

一とマも重要

重要

一やや重要 あまり重要でない 重要で存い
34. 自分向義務への忠誠心

一とマも重要

重要 やや重要 あまり重要でない 重要でをい

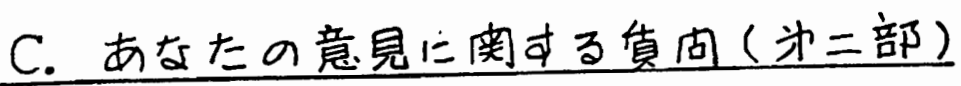

为一部と同じ要領で。あすたがもっともふされしいと思う ものに印をつけマ下さい。

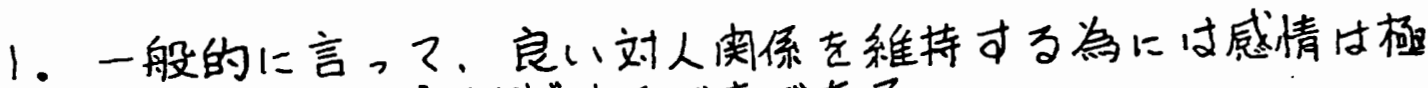
力押さえるよう心がけるべきである。

一全面的に替成 や替成

二どちらとも言えない や敒対

全面的に反対

2. プライベートな時间であっても、自分が所属する集团(例 えば、会社、教会、家族在ど)の為には艺の時间を惜しみ なく使うょう心が放ゔきである。

一全面的上替成

三地替成

二どちらとも言えない

一やや反対 全面的に反対

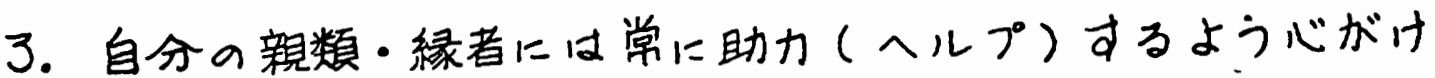
るべきである。

全面的に替成 やゃ賛成

一どちらとも言之ない やや反对 


\section{全面的に反対}

4.人は、光の人の生まれつきの性颠(男女の别、年令、人種、 家の地位など)によるよりも。充しろ「先の人加いままでし マきた事」を基隼として判断されるべきである。

\section{一全面的に替成}

やや替成

一どちらとも言えない

やや反対

全面的に反㧍

5.「親しい友人」の数は少なく保っよう心゙がけるべきである。 全面的に賛成 やや替成

どちらとも言えない やや反对

全面的に反㧍

ニれで全部です。ありがとうございました。

\section{Appendix I: The Follow-Up Letter--Japanese Version}

单略。

先日、日系アメリカ人の文化变容の研究に成してのアンケート 調查を受け取ったことと思います。この禁書きは、今回の調查の 成果が皆样一人一人の貴重な御協力にかかっていることを知、? いただくため出すことにしました。（もし既にアンクートを送 り返していただいていたのでしたら。二の葉書きを出す失礼をお 詫でいたしきす。) 皆樣のお名前は、ジョ一ジ乘野氏ならでに近 藤三郎氏の御好意によ。て得たものです。三゙めんどうくは思いま すが、是非しもアンケートに御記入の上。送师していただきき すようお願いします。編切日(1/16)は既に過ぎておりますがまだ 送っマいただいて楧いません。敬具一月十七日

蒌井敏雅 
Appendix J: The Developed Code Categories

Columns Code

Question No.

$1-3$
4
$5-6$
7
8

9

$10-11$

$\begin{array}{ll}10-11 \quad \text { "How long" in years }(00=\text { Not Issei, } \\ 12 & \text { Marital status (1=Married, } 2=\text { Single, }\end{array}$

Identification (001-)

Card Number (1)

Age

Gender $(0=$ Male, $1=$ Female $)$

A -1

$1=$ Issei, $2=$ Nise $i, 3=$ Sansei, 4=Father -

A- 2

Issei/Mother-Nisei, $5=$ Father $-\mathrm{Nisei} /$

Mother-Sansei, $6=$ Father-Caucasian

American/Mother -Issei, $7=$ Father -

Caucasian American/Mother-Nisei,

$8=$ Father - Caucasian American/Mother -

Sansei, $9=0$ ther, $0=$ No Answer (from

now on, N/A)

Prefecture ( $1=$ Hokkaido, $2=$ Tohoku,

$A-4 a$

$3=$ Kanto, $4=$ Chubu, 5=Kinki, $6=$ Chugoku -

Shikoku, $7=$ Kyushu-Okinawa, $9=\mathrm{N} / \mathrm{A}$,

$0=$ Not Issei) *

13 Work status ( $1=$ Work full time, 2=Work

$3=$ Widowed, $4=$ Divorced, $9=\mathrm{N} / \mathrm{A}$ )

A -5

part time, 3 =Unemployed or laid off,

A- 6

$4=$ Keep house, 5=Retired, 6=0ther,

14

$0=$ No occupation, $9=$ N $/ A$ )

Work status of the spouse (Same as

A- 7

above except $0=$ Not married)

15-17 Occupational categorization by

Duncan's classification (From 001 to

100 for each occupation, $000=$ No occupa-

tion, 555=Retired, $999=\mathrm{N} / \mathrm{A})$

18-20 Occupation of father (Same as above)

Family income $(01=$ Less than $\$ 2,500$,

$02=\$ 2,500$ to $4,999,03=\$ 5,000$ to 7,499 ,

$04=\$ 7,500$ to $9,999,05=\$ 10,000$ to

$12,499,06=\$ 12,500$ to $14,999,07=\$ 15,000$

to $17,499,08=\$ 17,500$ to $19,999,09=$

$\$ 20,000$ to $24,999,10=\$ 25,000$ to 29,999 ,

$11=\$ 30,000$ to $34,999,12=\$ 35,000$ to

$\$ 39,999,13=\$ 40,000$ to $44,999,14=$

$\$ 45,000$ to $49,999,15=\$ 50,000$ to 54,999 ,

$16=\$ 55,000$ to $59,999,17=\$ 60,000$ to

$64,999,18=\$ 65,000$ to $69,999,19=$

$\$ 70,000$ to $74,999,20=\$ 75,000$ and over,

$99=\mathrm{N} / \mathrm{A}$ ) 
23-24 Parents' income (Same as above.

$98=$ When the answer to the next question

is \# 4 or 5)

Certainty to the question \#11 ( $1=$ Very

Certain, 2=Fairly Certain, $3=$ Somewhat

Certain, $4=$ Uncertain, $5=I t$ 's just a guess, $9=\mathrm{N} / \mathrm{A}$ )

26-27 Education of yourself (01=None, $02=$

Some elementary school, 03=Completed elementary school, 04=Some junior high

school, 05=Completed junior high school, 06=Some high school, 07=Completed high

school, 08=Some college, 09=Completed

college, $10=$ Post graduate work, but no

advanced degrees, $11=0$ ne or more graduate

28-29 Education of father (Same as above)

30-31 Education of mother (Same as above)

32-33 Education of stepfather (Same as above)

34-35 Education of Stepmother (Same as above)

Kind of college: yourself ( $1=$ High pro-

fession including medical, dental and

1 aw school, $2=$ Low profession including

theology, M.B.A., education, or anything

beyond undergraduate school, $3=$ Regular

liberal arts, $4=$ Trade school including

community college, two-year business

school, or other education institutes

which teach skills, $8=$ No college education, $9=\mathrm{N} / \mathrm{A}$ )

Kind of college: father (Same as above)

Kind of college:

mother (Same as above)

Kind of college: stepfather (Same as above)

Kind of college: stepmother (Same as above)

Religious preference: yourself $(0=$ No preference, $1=$ Shinto, $2=$ Buddhism, $3=$

Christianity, $4=0$ ther, $9=\mathrm{N} / \mathrm{A}$ )

Religious preference: father (Same as above)

Religious preference: mother (Same as above)

Religious preference: stepfather (Same as above)

Religious preference: stepmother (Same as above)

Organization participation ( $0=$ Yes, $1=$ No, $9=\mathrm{N} / \mathrm{A}$ )

JAS participation $(0=$ Yes, $1=$ No or answered "no" in the question \#16) JAS: how many times ( $0=$ Answered "no" in the question above or \#16, $1=$ Never, $2=$ Less than once a month, $3=1$ or 2 a month, $4=3,4$ or more a month, $9=$ N $/ A$ ) 
49

50

51

52

53

54

55

56

57

$58-59$

JAWC participation (Same as column \#47)

JAWC: how many times (Same as column \#48)

JACL participation (Same as column \#47)

JACL: how many times (Same as column \#48)

Participation in other organization (Same

as column \# 47)

Other organization: how many times (Same as column \#48)

How many Japanese neighbors $(1=0,2=1-5$,

$3=6-10,4=11-15,5=16-20,6=21$ or over,

$9=\mathrm{N} / \mathrm{A}$ )

More Japanese friends than Caucasian

A-19

friends ( $1=$ Yes, $2=$ Half \& half, $3=$ No, $9=\mathrm{N} / \mathrm{A}$ )

Self-judged social class ( $1=$ =upper,

2=Upper Middle, 3=Lower Middle, 4=

Working, $5=$ Lower, $9=\mathrm{N} / \mathrm{A})$

Self-judged ethnic ID (From 01 to 10, $99=\mathrm{N} / \mathrm{A}$ )

*The detail regarding the prefectural classification is as follows:

1) Hokkaido: Hokkaido

2) Tohoku: Aomori, Iwate, Akita, Miyagi, Yamagata, Fukushima

3) Kanto: Tokyo, Kanagawa, Chiba, Ibaragi, Saitama,

4) Chubu: Yamanashi, Shizuoka, Nagano, Niigata,

5) Kinki: Osaka, Kyoto, Hyogo, Shiga, Nara, Wakayama, Mie

6) Chugoku-Shikoku: Yamaguchi, Hiroshima, Shimane, Tottori, Okayama, Tokushima, Kagawa, Kochi, Ehime

7) Kyushu-Okinawa: Nagasaki, Fukuoka, Kumamoto, Oita, Saga, Miyazaki, Kagoshima, Okinawa

\section{The Second Card}

\section{Columns Code}

Question No.

$1-3$

4

Identification (001-)

5

Card Number (2)

Rationality ( 5 =Very Important, $4=$ B - 1

Important, 3 =Somewhat Important, $2=$ Somewhat Unimportant, $1=$ Unimportant, $9=\mathrm{N} / \mathrm{A}$ ) 
Patience (Same as above)

Repayment of kindness (Same as above)

$\mathrm{B}-3$

Prudence (Same as above)

$B-4$

Asceticism (Same as above)

$\mathrm{B}-5$

Worship of ancestors (Same as above)

$B-6$

11

Individuality (Same as above)

$\mathrm{B}-7$

Respect for authority (Same as above)

B -8

Filial duty (Same as above)

Respect for one's superior (Same as above)

B -9

Pursuit of a hobby (Same as above)

$\mathrm{B}-10$

Courteousness (Same as above)

$\mathrm{B}-11$

$\mathrm{B}-12$

Appreciation of feelings (Same as

above)

B -13

Educational achievement (Same as

above)

Freedom (Same as above)

Self-discipline (Same as above)

$B-14$

$\mathrm{B}-15$

Responsibility (Same as above)

$\mathrm{B}-16$

Ambition (Same as above)

$\mathrm{B}-17$

$\mathrm{B}-18$

Credit to one's own name (Same as above)

$\mathrm{B}-19$

Success (Same as above)

Credit to the family name (Same as above)

$B-20$

Togetherness with one's clan (Same

B -21

as above)

$\mathrm{B}-22$

Improvement (Same as above)

$\mathrm{B}-23$

Sacrifice of today (Same as above)

B -24

Personal relations (Same as above)

$\mathrm{B}-25$

Self-control (Same as above)

$\mathrm{B}-26$

Humanitarianism (Same as above)

$\mathrm{B}-27$

Respect for property (Same as above)

$\mathrm{B}-28$

33

34

Respect for the Emperor (Same as

above)

B -29

Obedience (Same as above)

$\mathrm{B}-30$

Generosity (Same as above)

$\mathrm{B}-31$

Work as a virtue (Same as above)

$\mathrm{B}-32$

Proper behavior (Same as above)

$\mathrm{B}-33$

38

39

above)

B -34

Emotion/Personal relation ( $5=$ Agree

$\mathrm{C}-1$ completely, $4=$ Tend to agree, $3=$ Neutral, $2=$ Tend to disagree, $1=$ Disagree completely, $9=\mathrm{N} / \mathrm{A}$ )

Individual-group relation (Same as above)

Kin consciousness (Same as above)

Achievement-ascription value (Same as above)

43 Association consciousness (Same as above) 
Appendix K: Imperial Rescript on Education of 1890

Know ye, our Subjects:

Our Imperial ancestors have founded our empire on a basis broad and everlasting and have deeply and firmly implanted virtue; our subjects, ever united in loyalty and filial piety, have from generation to generation illustrated the beauty thereof. This is the glory of the fundamental character of our empire, and herein also lies the source of our education. Ye, our subjects, be filial to your parents, affectionate to your brothers and sisters; as husbands and wives be harmonious, as friends true; bear yourselves in modesty and moderation; extend your benevolence to all; pursue learning and cultivate arts, and thereby develop your intellectual faculties and perfect your moral powers; furthermore, advance the public good and promote common interests; always respect the constitution and observe the laws; should any emergency arise, offer yourselves courageously to the state; and thus guard and maintain the prosperity of our Imperial throne, coeval with heaven and earth. So shall ye not only be our good and faithful subjects, but render illustrious the best traditions of your forefathers.

The way here set forth is indeed the teaching bequeathed by our Imperial ancestors, to be observed alike by their descendants and subjects, infallible for all ages and true in all places. It is our wish to 1 ay it to heart in all reverence, in common with you, our subjects, that we may all thus attain to the same virtue.

From Jon Livingston et al. ed., Imperial Japan: $1800-$

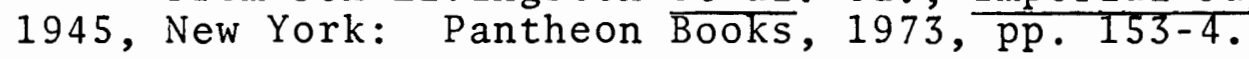

Appendix L: Rank Order of Values (Retained or Relinquished) for Issei, Nisei, Sansei and All Three Generations

Issei

Retained Values

1. Good personal relation

2. Prudence

3. Filial duty

4. Responsibility

5. Repayment of kindness which one received in the past
$\underline{S \text { core* }}$

4.760

4.692

4.667

4.654

4.556 
1. Willingness to sacrifice today for the gain in the future

2. Ambition

3.318

3. Success

3.409

4. Respect for one's superior

3.480

5. Pursuit of a hobby

* Scoring was utilized in the following method:

5 points for the category of "Very Important"

4 points for the category of "Important"

3 points for the category of "Somewhat Important"

2 points for the category of "Somewhat Unimportant"

1 point for the category of "Unimportant"

\section{Nisei}

Retained Values

1. Responsibility

2. Respect for property

3. Rationality

4. Prudence

5. Self-discipline

Relinquished Values

1. Respect for the Emperor

2. Worship of ancestors

3. Pursuit of a hobby

4. Generosity

5. Willingness to sacrifice today for the gain in the future $\underline{\text { Score }}$

4.590

4.550

4.500

4.500

4.500

$\underline{\text { Score }}$

2.421

3.316

3.625

3.775

3.821

\section{Sansei}

Retained Values

$\underline{\text { Score }}$

1. Appreciation of human feelings 4.545

2. Good personal relation

3. Freedom

4. Responsibility

5. Rationality

4.469

4.455

4.455

4.364

Relinquished Values

Score

1. Respect for the Emperor

2. Worship of ancestry

1.719

2. 576 
3. Proper behavior in accordance with one's status

2.758

4. Obedience

3.344

5. Willingness to sacrifice today for the gain in the future

3.375

A11 Three Generations

Retained Values

Score

1. Responsibility

2. Appreciation of human feelings

4.575

3. Good personal relation

4.514

4. Repayment of kindness which one

4.495 received in the past

5. Retionality

4.439

4.423

Relinquished Values

$\underline{\text { Score }}$

1. Respect for the Emperor

2.587

2. Worship of ancestry

3. Willingness to sacrifice today

3.302 for the gain in the future

3.451

4. Pursuit of a hobby

3.561

5. Proper behavior in accordance with one's status

3.593 